\title{
USDA
}

United States

Department of

Agriculture

\section{Delivering the Goods:}

Agricultural

Marketing

Service

Lessons Learned from Direct

March 2007

\section{Delivery of Kentucky Catfish}
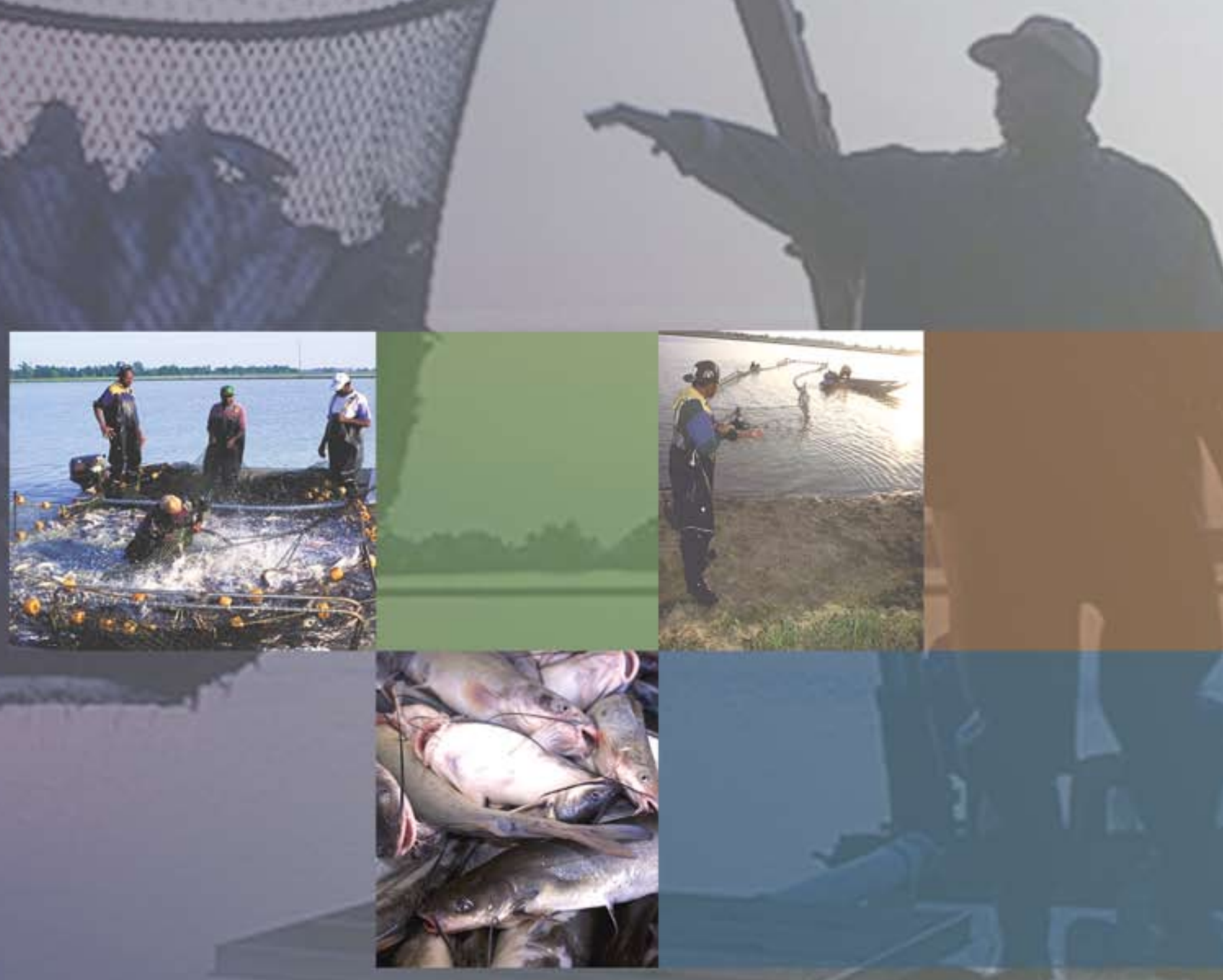


\section{Delivering the Goods: Lessons Learned from Direct Delivery of Kentucky Catfish}

by:

Gerald Berney, Agricultural Engineer

Debra Tropp, Supervisory Agricultural Marketing Specialist

Kimberly Clifton, Marketing Intern

Larissa McKenna, Marketing Intern

Transportation and Marketing Programs 


\section{Preferred Citation}

Berney, Gerald, Debra Tropp, Kimberly Clifton, and Larissa McKenna. Delivering the Goods: Lessons Learned from Direct Delivery of Kentucky Catfish. U.S. Department of Agriculture, Agricultural Marketing Service, March 2007. Web. $<$ http://dx.doi.org/10.9752/MS025.03-2007>

\section{United States Department of Agriculture}

Agricultural Marketing Service

Washington DC 20250

March 2007

The U.S. Department of Agriculture (USDA) prohibits discrimination in all its programs and activities on the basis of race, color, national origin, age, disability, and where applicable, sex, marital status, familial status, parental status, religion, sexual orientation, genetic information, political beliefs, reprisal, or because all or part of an individual's income is derived from any public assistance program (Not all prohibited bases apply to all programs.) Persons with disabilities who require alternative means for communication of program information (Braille, large print, audiotape, etc.) should contact USDA's TARGET Center at (202) 720-2600 (voice and TDD).

To file a complaint of discrimination, write to USDA, Director, Office of Civil Rights, 1400 Independence Avenue, S.W., Washington, D.C. 20250-9410, or call (800) 795-3272 (voice) or (202) 720-6382 (TDD). USDA is an equal opportunity provider and employer.

Brand names of equipment are used in this report as an aid to the reader's understanding and do not represent any form of endorsement by USDA over other manufacturers or products. 


\section{Foreword}

This research project was carried out under a cooperative agreement between the Kentucky Department of Agriculture (KDA) and the U.S. Department of Agriculture (USDA), Agricultural Marketing Service (AMS). The Purchase Area Aquaculture Cooperative (PAAC) provided the data used in the study and received reimbursement from KDA for some of the expenses involved in implementing direct deliveries of catfish to food-service and retail customers. KDA handled the administrative duties for the agreement and USDA provided funds, performed the analysis, and wrote the results.

Several factors prompted the initiation of this study:

1. Small growers in many parts of the country are turning to alternative and niche production and marketing enterprises. Marketing and delivery strategies that further sales while keeping operating costs reasonable are crucial for the success of these enterprises.
2. There is a dearth of information about delivery and distribution, especially in relation to smaller agricultural enterprises. Most of the bulletins published by landgrant universities and Cooperative Extension departments address production costs and procedures-how to grow a high-quality crop at a reasonable cost and solve problems that arise during production. But they often fail to address transportation and delivery issues, the cost of which can represent a significant portion of the product's market value.

This study was designed to identify the costs and benefits of implementing direct delivery systems for high-value, perishable farm products and to share this information with other start-up farm marketing operations. We hope this information helps start-ups better understand how their decisions affect delivery costs, sales volume, customer goodwill, and profitability.

The authors would like to acknowledge the efforts of the following organizations and individuals without whose help this project would not have come to fruition:

- James Mansfield, Angela Caporelli, and Anna Sidebottom Lucio, KDA, Frankfort, KY.

- Tom French and Kim Witherspoon, PAAC, Tri City, KY. 


\section{Summary}

USDA initiated a pilot study in cooperation with KDA and PAAC that examined the marketing, transportation, and delivery strategies of the catfish processing cooperative. The information gathered should prove useful to many groups involved in this type of enterprise. The study had several emphases:

- Describing the marketing channels, customers, and products used by the cooperative in selling catfish.

- Describing the procedures and equipment used in PAAC's direct delivery operation.

- Examining the cost components of operating a leased 3/4-ton Chevrolet refrigerated delivery truck.

- Examining the costs of contracted tractor-trailer delivery of palletized lots of catfish to a large chain store warehouse.

\section{Marketing}

When PAAC began its processing operation, most of its customers were small firms that received regular shipments of small quantities of catfish. PAAC delivered catfish products to a variety of small grocers, restaurants, and retirement homes. Other customers included small wholesalers, restaurant chains, and a major grocery chain. The larger customers bought larger quantities at lower per-unit delivery costs, but were more difficult to serve because of their specific packaging, labeling, and inspection requirements. PAAC passed on some of these costs, such as inspection, to the customer.

A major change occurred when a large grocery chain began ordering a large share of PAAC's output. Smaller customers remained consistent buyers, but adding this single large buyer doubled the demand for the cooperative's fish products. The introduction of a larger scale buyer not only has the ability to increase demand dramatically, but also to disrupt demand if the buyer curtails purchases.

The lack of demand for chilled fish was surprising. Contrary to expectations, the market preferred the convenience and shelf life of the frozen product to the benefits of chilled (never frozen) fish.
An unexpected assist for the cooperative was the discovery of food banks as a market for excess inventory, or slightly off-grade products. Even though food banks received a discounted price, sales to them allowed PAAC to recover some cost on items that were clogging inventory, adding to storage costs, and that might otherwise be a total financial loss.

\section{Delivery}

During the study, half the fish processed by PAAC was delivered by contracted trucking firms to a single large retail customer's central warehouse. The other half was delivered directly to many smaller customers by PAAC. The large customer required that the fish be inspected, which necessitated driving loads of fish first to Indianapolis for inspection at a government facility, then to the customer's distribution warehouse in Louisville. Despite the extra cost associated with inspection, delivering multi-pallet loads of catfish cost between 7 and 15 cents a pound, one-half of the 30 cents a pound it cost to deliver small orders.

Small orders usually consisted of less than a hundred pounds of fish, delivered weekly with a leased, refrigerated 3/4-ton pickup. The annual cost to operate the truck between September 2002 and August 2003 was $\$ 53,699$, just over 63 cents a mile. The largest part of this cost was for leasing $(47 \%)$, followed by labor $(24 \%)$ and fuel $(20 \%)$.

PAAC paid an average of only $\$ 8$ an hour for drivers, including fringe benefits. In contrast, the median hourly driver pay in 2002 in the specialty food industry was $\$ 14.98$ (Bureau of Labor Statistics, 2005). This would make the full cost of labor, including fringe benefits, close to $\$ 21$ an hour. If PAAC had paid this much for a driver, the total operating cost of the truck would have been 91 cents a mile. With the rising cost of benefits and a shortage of competent drivers, higher labor charges would appear to be likely. 


\section{Contents}

Foreword

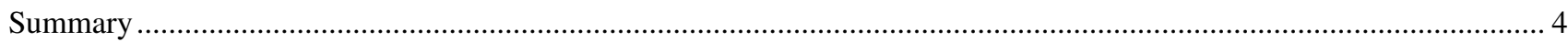

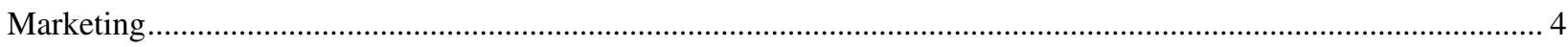

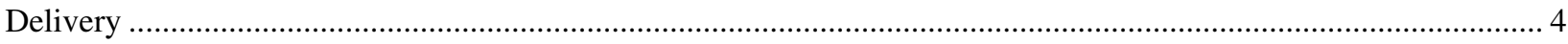

Introduction

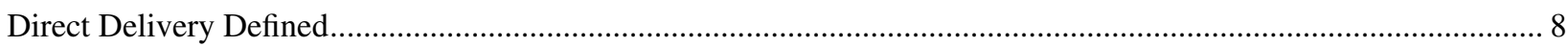

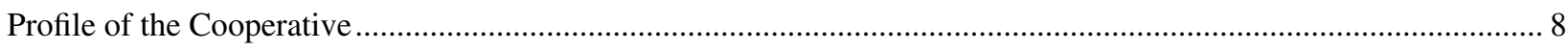

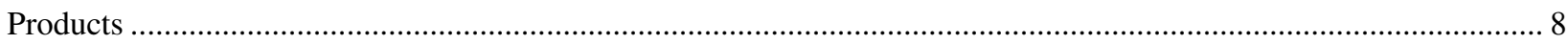

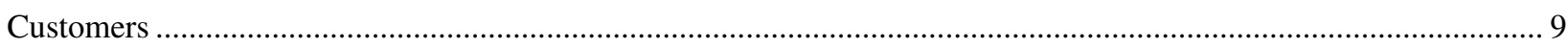

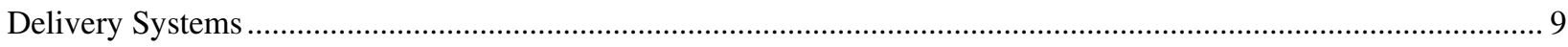

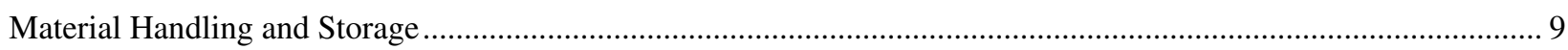

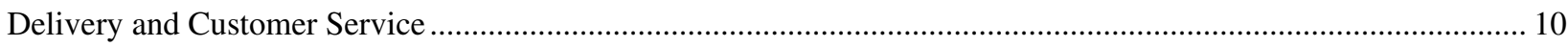

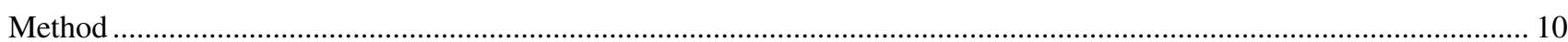

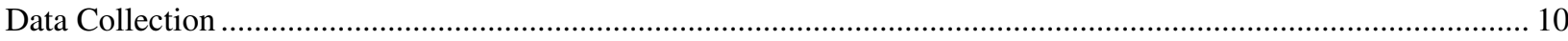

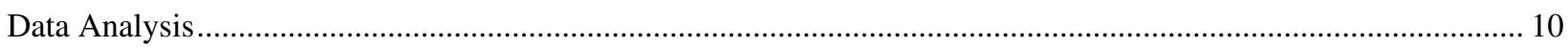

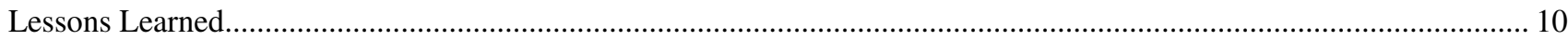

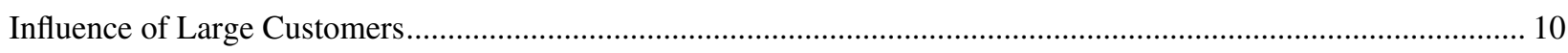

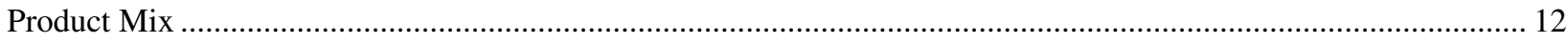

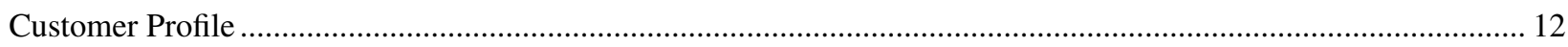

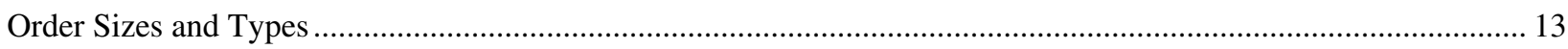

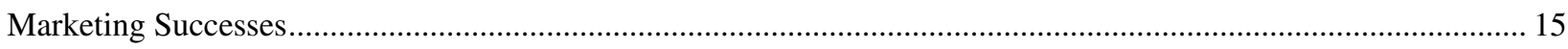

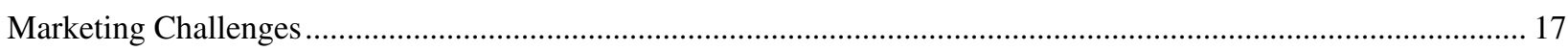

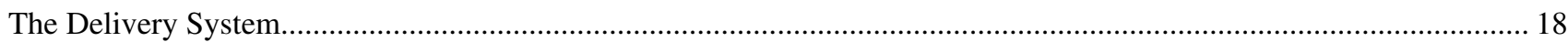

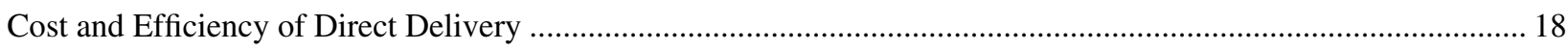

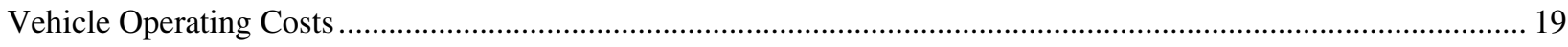

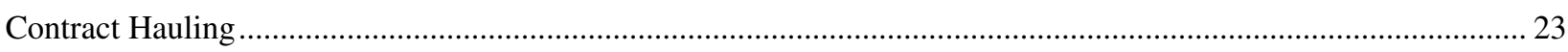

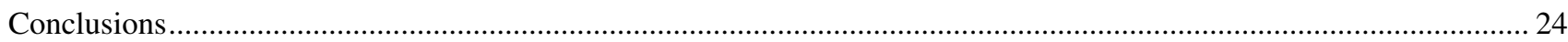

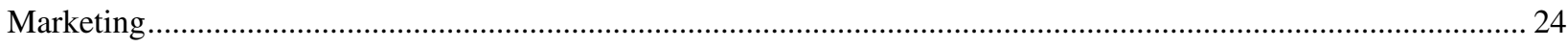

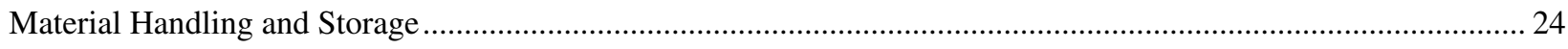

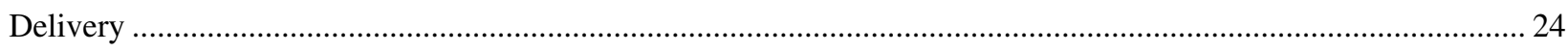

Improving the Delivery Operation........................................................................................................... 24

Appendix

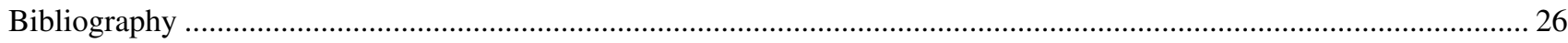




\section{Figures}

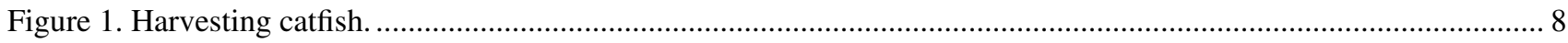

Figure 2. A pickup truck equipped with an insulated slide-in box and refrigeration unit. ............................................. 9

Figure 3. An example of the computer-generated routing maps used by PAAC to ensure

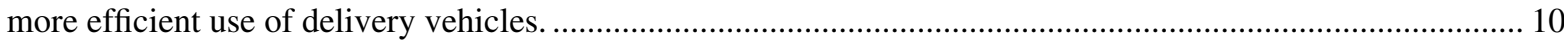

Figure 4. Pounds of fish delivered directly to customers in the leased truck and by contract

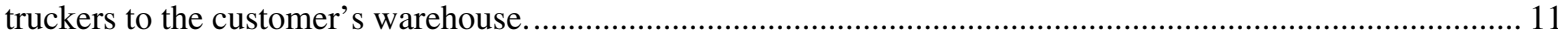

Figure 5. Share of deliveries made by the leased truck and by contract haulers .......................................................... 11

Figure 6. Catfish ready to be processed into fillets, nuggets, and strips. .................................................................... 12

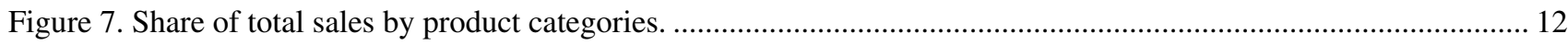

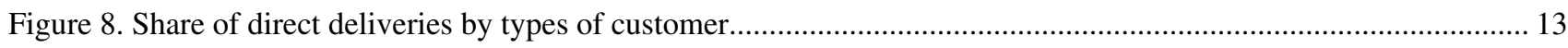

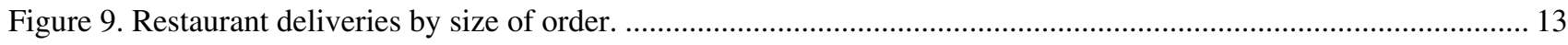

Figure 10. Deliveries to wholesalers by order size.

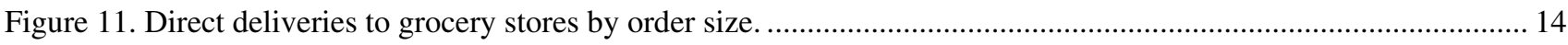

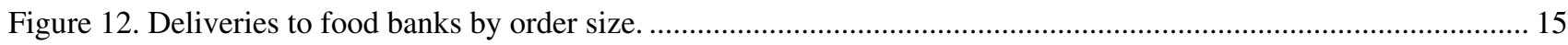

Figure 13. Banners and placards advertising local catfish at a restaurant in Murray, Kentucky ...................................... 16

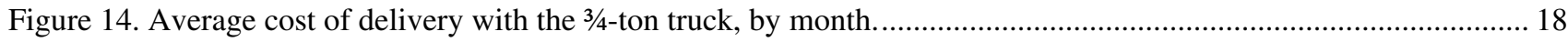

Figure 15. U.S. at-pump diesel fuel cost, September 2002-August 2003 ............................................................... 20

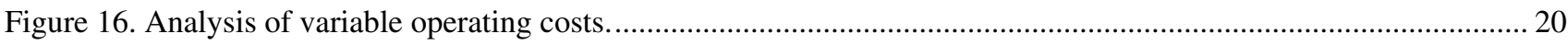

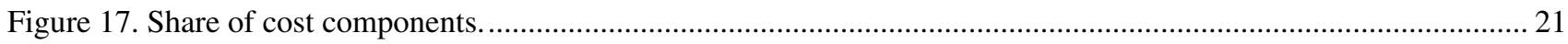

Figure 18. U.S. at-pump diesel fuel cost, January 2002-December 2004 ................................................................ 22

Figure 19. The effect of diesel fuel price increases on the operating cost of the cooperative's truck.............................22

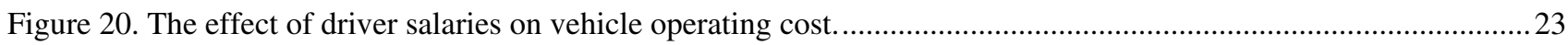

\section{Tables}

Table 1. Purchase price of truck, insulated freezer box and refrigeration unit (2002 dollars). ......................................... 19

Table 2. Annual fixed costs of 2-year lease on a 3/4-ton, refrigerated truck, September 2002-August 2003..................... 19

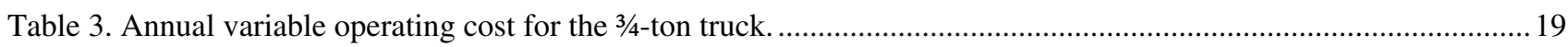

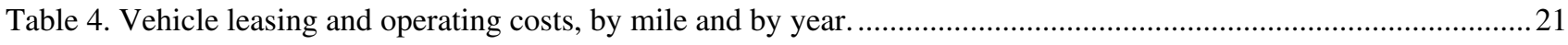

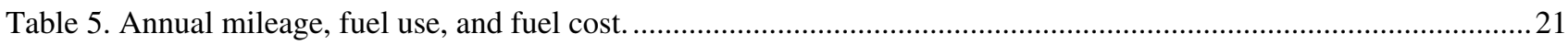

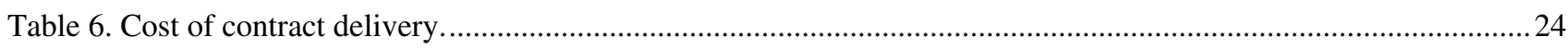




\section{Introduction}

When farmers form marketing cooperatives, they usually carry out market feasibility studies. Some fundamental questions answered during this process are: "What will be produced?" and "Who are the customers?" However, a question that is often overlooked is: "How will the products be delivered and how and much will it cost?"

Start-up agricultural enterprises face many challenges in attracting larger customers. They are usually small, and can fill only small orders, so their lack of capacity restricts them from selling to large customers. In addition, their lack of a track record causes large customers to hesitate before conducting business with an unfamiliar entity. Established commercial buyers look for dependable suppliers with enough production capacity to fill their needs. Start-up firms without a reputation have no good method to demonstrate their reliability and dependability.

The food distribution system in the United States is comprised primarily of supermarket chains, national distribution companies (which primarily serve the growing foodservice industry), and large mass-merchandise retailers and wholesale club/supercenter operators such as Costco, Target, Wal-Mart, and Sam's Club. Independent retailers and small grocery chains sell a declining share of the food purchased in the United States, due to changes in customers' buying habits, more competitive pricing, or the general consolidation in the industry. In 2005, the top 20 grocery chains accounted for 68 percent of grocery sales, up from 40 percent in $1992 .{ }^{1}$ Wal-Mart alone had $\$ 79.7$ billion in grocery sales during 2004 and a 17.4 percent U.S. market share, making it the Nation's largest food retailer. ${ }^{2}$ This consolidation results in fewer buyers and thus fewer opportunities to make sales.

Because the consuming public spends a significant portion of its food budget at these outlets, it would seem logical for start-up enterprises to attempt to gain access to them. Unfortunately, access is impeded by barriers, such as the consolidation of the food retailing industry, flat consumer demand, the plethora of new food products, and increasingly stringent requirements for packaging, labeling, and traceability.

Economic Research Service, USDA, "Food market structures," Briefing Room http://www.ers.usda.gov/Briefing/FoodMarketStructures/.

2 Bloomburg, 2005, "Wal-Mart grocery sales rise 2.5\%," Business Day, 29 May, http://www.biz-day.com/read/commodities/.

3 Pyle, R., 1995, "Statement before the Federal Trade Commission slotting fees hearing by Robert N. Pyle, President, Independent Bakers Association," Federal Trade Commission, 8 Nov, http://www.ttc.gov/opp/global/slott.htm.

4 Oligopoly Watch, 2003, "Slotting fees and oligopolies," 8 May, http://www.oligopolywatch.com/2003/05/08.html.
Twenty thousand new grocery products are launched each year, but a typical grocery store carries only about 30,000 items. New products and new suppliers of established products must somehow supplant the current holders of shelf space. However, existing suppliers have spent years cultivating relationships with the large retailers for that space, which may be why some retailers now charge a new product placement or "slotting" fee. Slotting fees vary widely, but may be as much as $\$ 200,000$ per item. ${ }^{3}$ The grocery industry nets $\$ 9$ billion in fees per year. ${ }^{4}$ However, fees are more likely to be applied to highly processed and specialty foods such as baked goods, preserves, snack items, and frozen food than to raw produce, meat, fish, or poultry.

Large retailers often demand special services from their suppliers, such as custom labeling, product identification, special sizes and weights of packages, inspections, and certifications of various types. These special services and specifications add to the producers' cost of selling to larger retailers. The low price some of these firms are willing to pay also makes it difficult to serve large retailers. Low prices favor the largest and most efficient producers.

The "buy local" movement runs counter to the trend toward greater consolidation. ${ }^{5}$ Consumers have become more interested in local farmers markets, State-branded produce (Jersey Fresh, Kentucky Pride), local "farm to school" initiatives, ${ }^{6}$ and such regional promotional programs as Delaware, Maryland, and Virginia's "Shore to Store" Program. Shore to Store is a referral service connecting supermarkets looking for local produce with farmers who want to sell locally. State officials report a steady increase in the volume of sales through this program.

Restaurants, specialty food stores, and even chain stores increasingly feature locally produced items in their bills of fare. One Mid-Atlantic grower's cooperative, Tuscarora Organic Growers, has gained regional fame by providing highquality local produce to high-end restaurants and specialty food stores in the lucrative Baltimore-Washington market. ${ }^{7}$

Despite the increased interest by some major food chains in selling locally produced farm products, most start-up agribusiness firms, because of their limited production and distribution capacity, need to build their customer bases on smaller clients, such as independent grocery stores and res-

\footnotetext{
5 Food Routes, 2005, Buy Fresh, Buy Local campaign, http://www.foodroutes.org/.

6 Tropp, D. and S. Olowolayemo, 2000, How Local Farmers and Food Service Buyers are Forming Alliances, USDA, Agricultural Marketing Service, http://www.ams.usda.gov/tmd/MSB/PDFpubList/localfarmsandschool.pdf.

7 Tuscarora Organic Growers, 2005, http://www.tog.coop/.
} 
taurants, delicatessens, churches, and nursing homes. Most of these small customers require delivery service because they lack their own trucking, warehousing, and distribution systems. A delivery system capable of serving these small clients can help establish a loyal pool of customers. This study investigates how such a delivery system works, how much it costs, and how it affects profitability.

\section{Direct Delivery Defined}

Direct delivery, as the name implies, is a distribution method in which the producers deliver their products directly to the customer's restaurant, store, or other place of business without the use of an outside trucking, broker, or distribution service. Generally, an owner or employee delivers products with an owned or leased vehicle. This allows for direct, regular contact with customers, which has advantages for both the company and the customer-customers receive more personalized and responsive service, while the company benefits from the feedback it receives. However, these direct delivery arrangements require labor, equipment, and management commitments.

Unlike a few large food manufacturers who "self-distribute" their products, most agricultural producers market farm products through a highly developed set of intermediaries: brokers, specialty wholesalers, and food distribution companies. While such intermediaries provide useful service and add value in the marketing chain, they also receive the lion's share of the sale price. Farmers are receiving a decreasing share of the consumer's food dollar-averaging less than 19 percent of the retail price. ${ }^{8}$ Capturing a larger share of the final sale price helps small producers and startup food companies to remain viable. An effective directdelivery system enables small producers to gain a greater share of the consumer food dollar by reducing the number

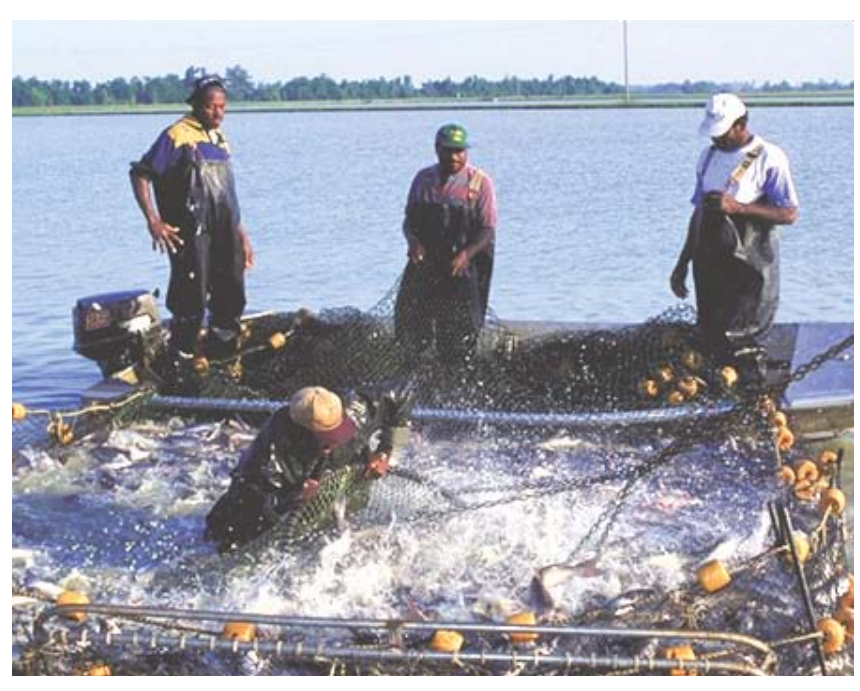

USDA file photo

Figure 1. Harvesting catfish. of intermediaries between them and their customers.

\section{Profile of the Cooperative}

The Purchase Area Aquaculture Cooperative (PAAC) is a member-owned organization with approximately 50 members. Organized in 2000, PAAC grows, processes, and markets catfish. Purchase Area is the name of a region in western Kentucky.

\section{Products}

Much of the cooperative's production is delivered directly to the customer as either chilled or frozen catfish products. Frozen fish are fairly stable, but chilled (fresh) fish are highly perishable. (The industry uses the word "chilled" rather than "fresh" for fish that have never been frozen because "fresh" is often used to mean "not old.") Both chilled and frozen fish require careful temperature management. The catfish are sold in 5-, 10-, 15-, or 20-pound cartons, depending on customer needs. A price list for walk-in customers is shown in the Appendix. Prices charged to delivery customers were not shared with AMS, nor was profit information.

Cooperative members grow catfish in outdoor, man-made ponds. They purchase fish as fingerlings and sell them as market-sized fish 18 months later, weighing about 1.25 pounds. Water temperature and quality are extremely important. The fish grow best in warm water-85 degrees is optimum. Colder water reduces metabolism and feeding; the growth rate is halved with each 18-degree drop in water temperature. Catfish will survive colder water temperatures, but do not grow much. The cooperative harvests, processes, and delivers fish nearly year-round. Although it is difficult to harvest fish out of frozen ponds in midwinter, the generally mild weather in the cooperative's growing area, combined with the cooperative's ability to store frozen fish, allows business to continue with little interruption even in January and February.

The cooperative sells several products:

Fillets are cut from the side of the skinned fish, with the belly meat trimmed off. The cooperative sells them in three sizes.

Deep skinned fillets have been more thoroughly skinned than regular fillets and bring a higher price.

Strips are cut from fillets.

Nuggets are cut from belly meat trimmed from the fillet. They are by-products of making fillets.

Steaks are cut all the way across the fish, including both sides.

\footnotetext{
8 "Calculating the Food Market Bill," Amber Waves, USDA Economic Research Service, February 2004, http://www.ers.usda.gov/AmberWaves/February04/ Indicators/behinddata.htm.
} 
Fiddlers are whole gutted and skinned fish.

Customers order far more filleted fish than any other product, and far more frozen fillets than chilled. The demand for fillets was not surprising because fillets are a familiar and popular product among catfish consumers, but the preference for frozen products surprised the cooperative's management. Their marketing plan anticipated that chilled catfish that has never been frozen would be popular in the local market. Chilled catfish, it was thought, would be a unique local product that distant competitors could not provide. However, the market for chilled catfish never materialized. The Marketing Challenges section of this report explores this phenomenon.

\section{Customers}

The cooperative sold catfish to smaller independent grocery stores and restaurants, regional restaurant chains, regional supermarket chains, church groups, caterers, health care institutions, food banks, and wholesale fish distributors. Most of these customers supported local farmers by purchasing locally grown products and many advertised the fish as locally produced.

\section{Delivery Systems}

Prior to this study, deliveries were made with a variety of leased, owned, and contracted refrigerated vehicles. The principal delivery vehicle was a large, older, high-mileage Chevrolet C64 refrigerated van. This truck was larger than necessary for the small size of most deliveries. Due to its size and age, it had both high fuel usage and regular mechanical breakdowns.

Because an accurate assessment of direct delivery costs could be made only with an appropriate vehicle, this study provided funds to lease a smaller, more efficient, dieselpowered $3 / 4$-ton refrigerated delivery truck. A unit similar to that leased by the cooperative is shown in figure 2 .

The cooperative agreed to provide records of expenses, fuel use, time, mileage, and size of orders made with this truck. Although some deliveries used other small vehicles, the vast majority of direct deliveries during this study were made with the leased pickup.

Large chain operations and wholesalers with centralized warehouses and their own distribution systems were generally served by a contract hauler. The cost of contract hauling is analyzed separately on page 23 .

\section{Material Handling and Storage}

The material handling system used by the cooperative for the incoming live fish was well designed and efficient. It included carefully designed and constructed dump areas for the incoming fish, along with holding tanks and flumes that fed directly into the processing area. Fish and water could be moved by gravity from the truck to a holding tank and then into the processing area by simply lifting a gate.

In contrast, the method used to load trucks after processing was inefficient. Trucks were loaded by hand from the ground without benefit of loading docks, fork lifts, or other aids. This laborious process might have been adequate earlier, but as the number of deliveries grew, it created a bottleneck in production and cost more than a more efficient system would have.

As production increased, the cooperative outgrew its refrigerator and freezer storage space and was forced to look for additional cold storage. Until it could build more on-site storage, it used a combination of off-site commercial storage and temporary on-site storage. The off-site storage facility was more than 70 miles away, which added to trucking costs. The temporary on-site storage consisted of refrigerated trailers provided for a small fee by contract haulers. The trucking firms that delivered large orders to chain grocery warehouses delivered their trailers long in advance of scheduled deliveries. Material handling between the plant and the various storage sites was generally cumbersome and inefficient.

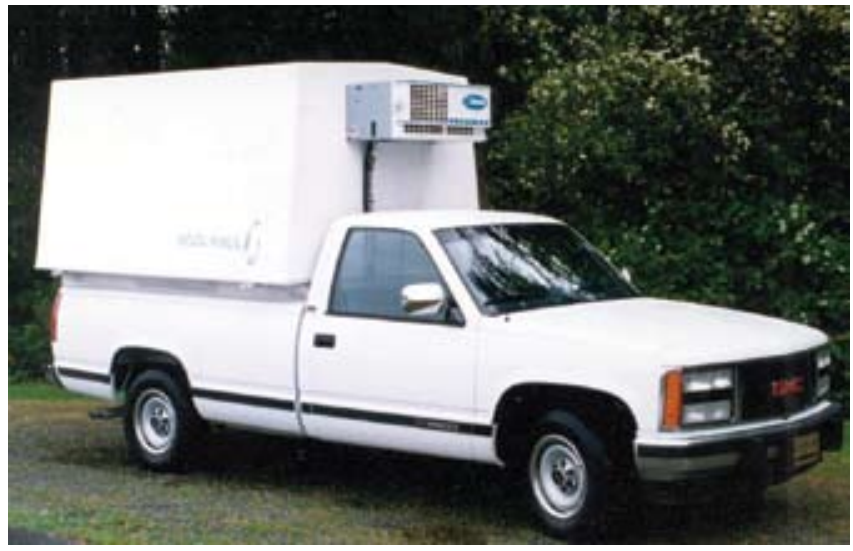

Photo courtesy of Horizon Fiberglass Products Ltd, Vancouver, BC

Figure 2. A pickup truck equipped with an insulated slide-in box and refrigeration unit. 


\section{Delivery and Customer Service}

Product orders were taken by sales and clerical staff at the plant, mostly by telephone. A delivery manager used a simple program on a personal computer to plot the most efficient delivery route (figure 3 ). This type of route management software, often used in conjunction with Global Positioning System (GPS) equipment, is widely used in the trucking industry. Several companies offer a range of products, from simple route planning programs such as the one PAAC used to interactive models that adjust for changes in traffic, delays, and order changes "on the fly." The more complex systems allow route changes and delivery schedules to be transmitted to the driver while the truck is on the road.

Deliveries were made by individual drivers without help from an assistant. The drivers were trained only to make deliveries, not to increase sales, solicit orders, or determine the customers' satisfaction. Drivers were paid only $\$ 8$ an hour, offering them little incentive to increase the sales or develop customer loyalty and goodwill. The cooperative missed an opportunity here-a motivated delivery person, with some sales training and financial incentives, can promote sales and obtain useful feedback from customers.

\section{Method}

This study consisted of three primary segments: data collection by the cooperative, data analysis by AMS, and site visits by AMS to observe the marketing and delivery activities.

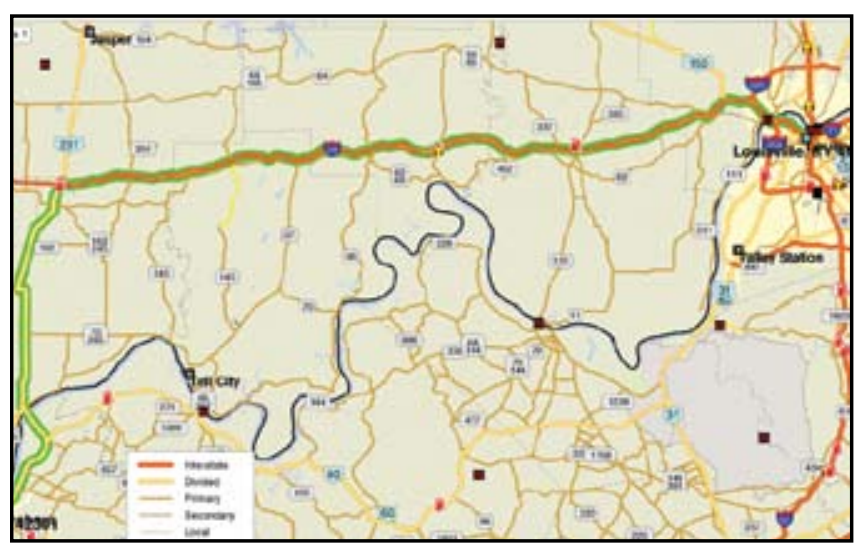

PC*Miler Map courtesy of Axron International, Saskatoon, Saskatchewan, Canada

Figure 3. An example of the computer-generated routing maps used by PAAC to ensure more efficient use of delivery vehicles.

\section{Data Collection}

Data was entered into a database program using an input form supplied by AMS. The drivers recorded fuel purchases, miles driven, quantity and type of product, customer, time, and date. The cooperative's clerk entered the data into the database, and the updated information was transmitted each month to AMS as an e-mail attachment. Besides this daily $\log$, information concerning the vehicle lease, insurance, labor, maintenance, license, fees, taxes, and registration was also collected by AMS.

Information regarding the cost of a contract hauler, including the trucker's fees, warehousing and inspection fees, and costs of loading and unloading was also collected and compared with the costs of direct delivery using the leased truck.

\section{Data Analysis}

The quality of the collected data varied, depending on the driver who collected it (several drivers were employed during the study) and the clerks who entered it. AMS checked each submission for errors and omissions, then contacted the cooperative in an attempt to correct the submission.

AMS generated monthly reports of the number of miles driven, the amount of fuel used, the pounds and types of products delivered, and the types of customers served. The reports also calculated average delivery costs per pound and per mile.

\section{Lessons Learned}

The study was able to draw two conclusions from the data-the key influence of large customers and large orders and the market's preference for frozen fish and for locally raised fish.

\section{Influence of Large Customers}

As the fledgling cooperative began to develop its market, most sales were to small customers, who usually received weekly deliveries of a few 15-pound boxes. During the study period, however, a grocery chain began placing much larger orders-for several 1,200-pound pallets of fish at a time. Deliveries to this chain made up about half the cooperative's production.

Figures 4 and 5 show the effect this single large customer had on the cooperative's business. Volume varied from 10,000 pounds in September 2002 to 70,000 pounds in March 2003. Most of this difference was due to those larger orders placed by the grocery chain. 


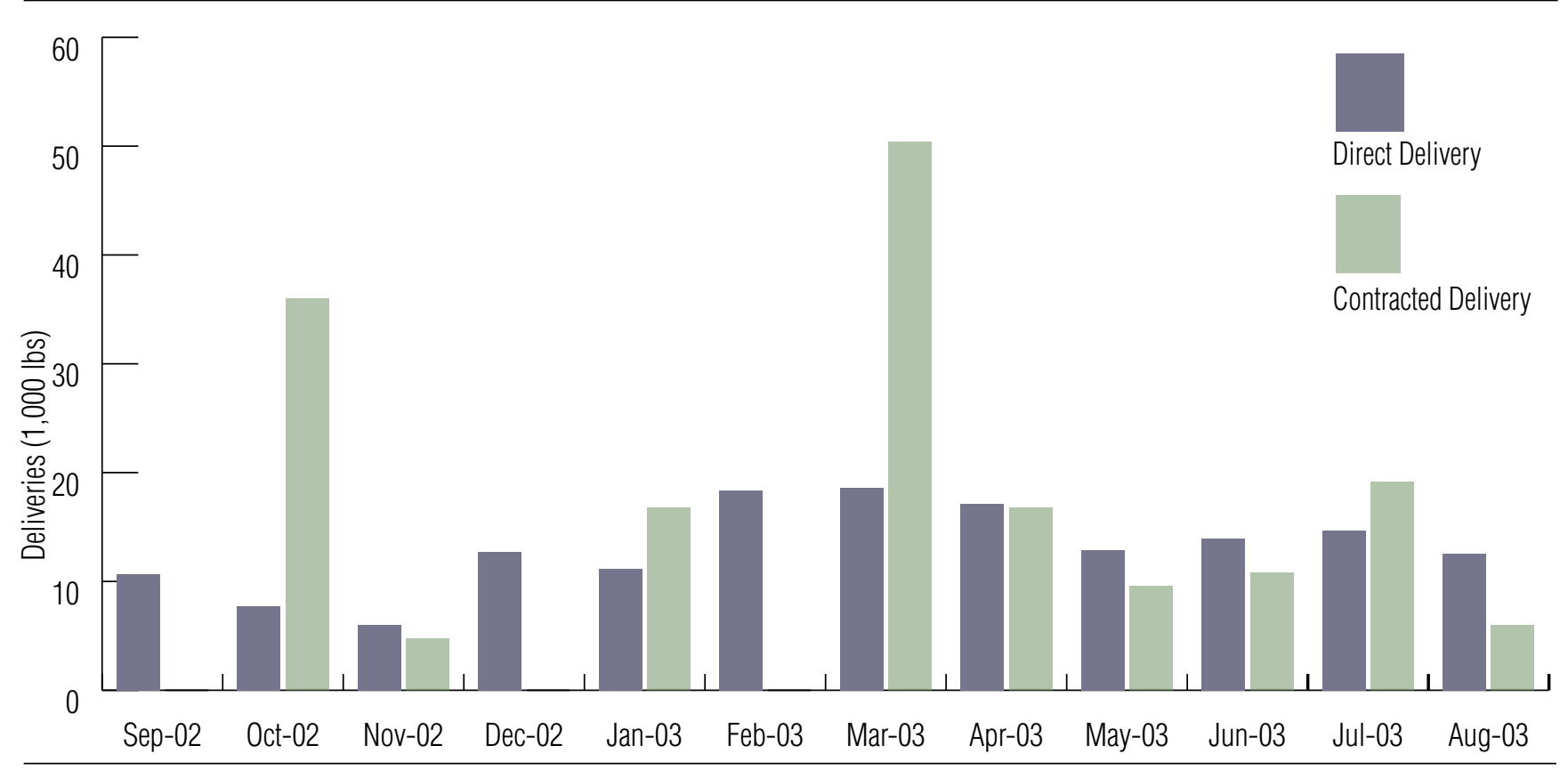

Figure 4. Pounds of fish delivered directly to customers in the leased truck and by contract truckers to the customer's warehouse.

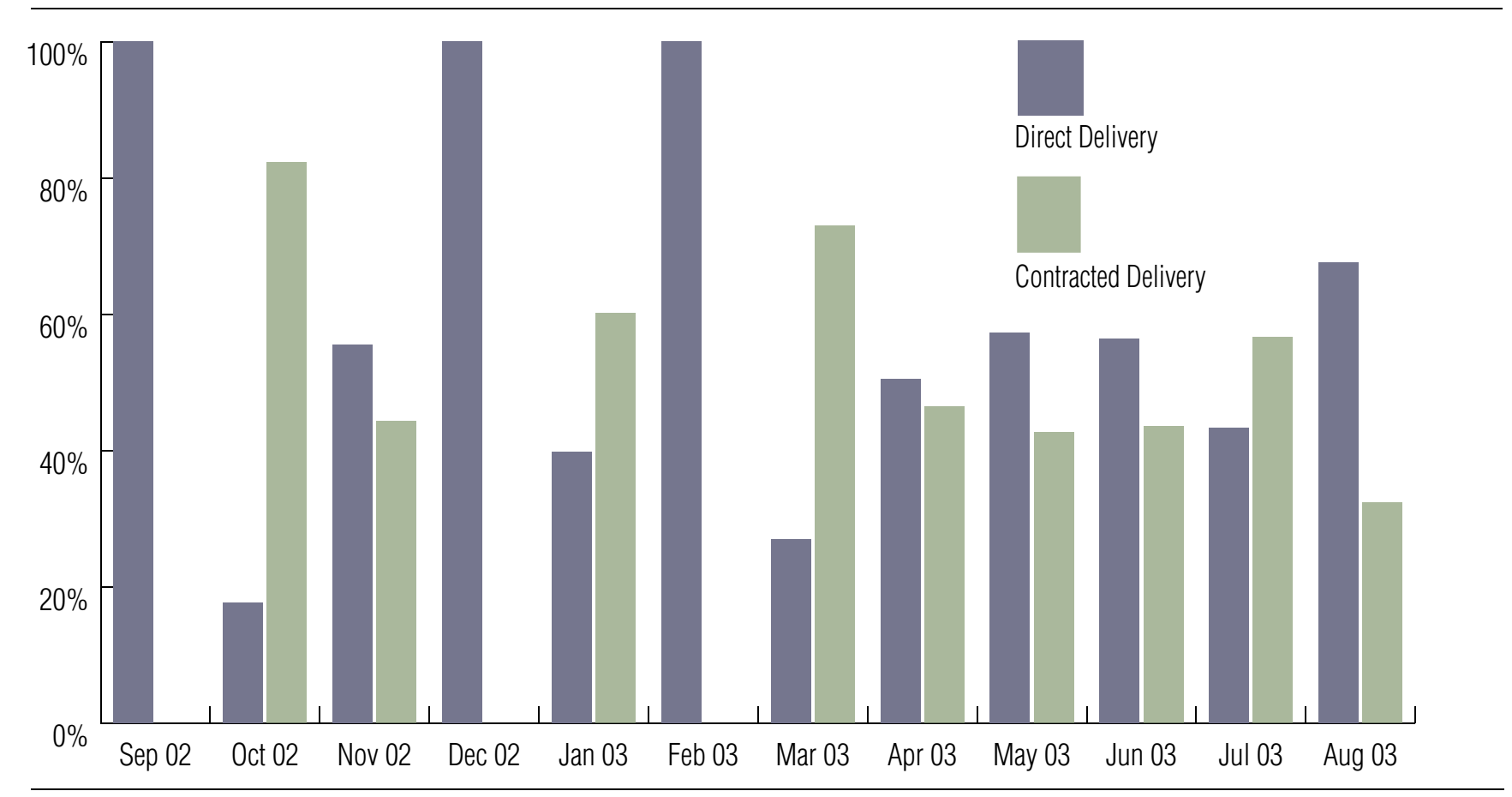

Figure 5. Share of deliveries made by the leased truck and by contract haulers. 


\section{Product Mix}

Frozen fillets dominated the sales (figure 7), accounting for 78 percent of the cooperative's catfish deliveries. Nearly two-thirds of this volume was purchased by a single supermarket chain. Chilled fillets accounted for only 13 percent of deliveries, and non-fillet items (both frozen and chilled) for only 9 percent of deliveries.

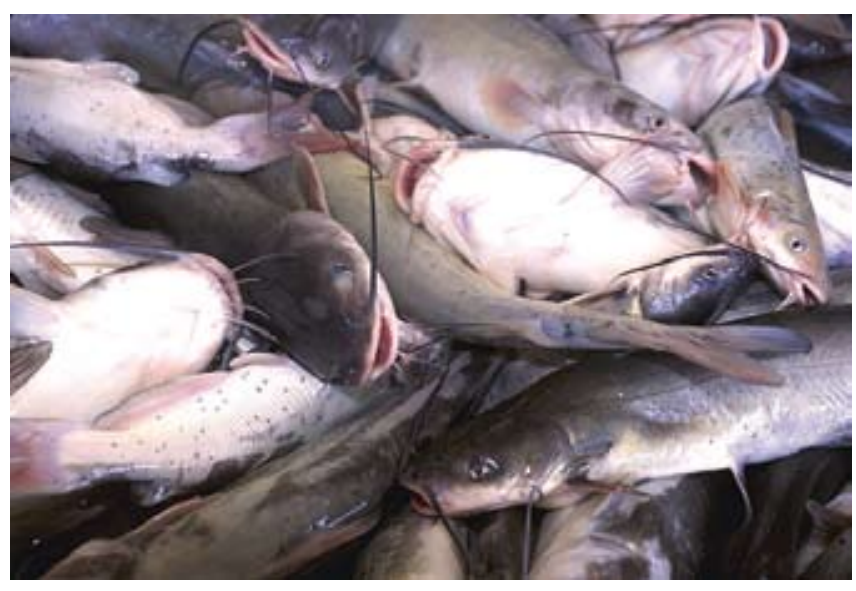

USDA file photo

Figure 6. Catfish ready to be processed into fillets, nuggets, and strips.
The preference for frozen over chilled catfish surprised the cooperative. Many suppliers of frozen fish-catfish from the Southern U.S. and similar fish from Southeast Asia-are able to supply local customers at competitive prices. The cooperative had assumed that its ability to provide a unique (chilled, never frozen) product would differentiate it from the competition. It had even hoped for a price premium for this exclusive product, but these expectations were overly optimistic. Instead, the cooperative found it difficult to create a market for any products other than frozen fillets. The lack of interest in products other than fillets (which is explored further in the Marketing Challenges section of this chapter) resulted in an accumulation of these productsespecially nuggets, which are a by-product of trimming fillets-and forced the cooperative to sell them at a discount to local food banks and pantries.

In spite of suffering a price disadvantage against stiff competition, the cooperative was able to build a steady interest in its frozen fillets because it offered a local product. This local product identity is a phenomenon that is discussed in greater detail in the section Marketing Successes.

\section{Customer Profile}

The cooperative sold catfish to several different types of customers, as shown in figure 8. Catfish is a staple of southern cuisine and is a typical menu item on many bills of

\section{Deliveries}

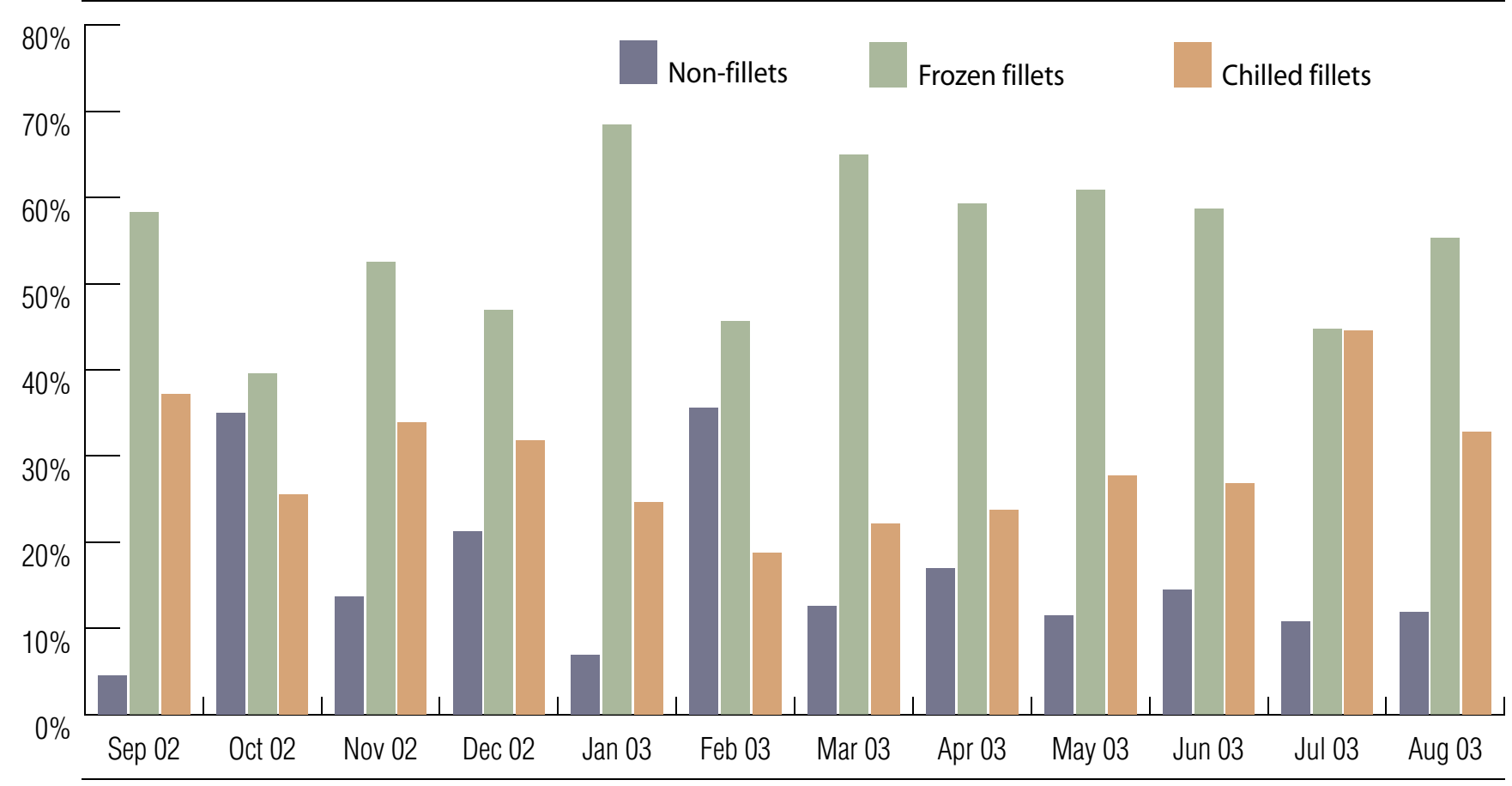

Figure 7. Share of total sales by product categories. 
fare. Specialty seafood restaurants in this part of the country normally feature this fresh water fish along with shrimp and saltwater fish. Because of the decrease in wild fish catches, the popularity of protein-rich diets, and the increase in the price of saltwater fish, catfish is a reasonably priced alternative to other seafoods.

The cooperative delivered directly to:

- Grocery stores

- Restaurants and delicatessens, both chain and independently operated

- Wholesalers

- Caterers

- Food banks

- Food-service institutions (including retirement homes)

- Other customers (such as churches and State park foodservice facilities)

Although a handful of customers picked up their orders from the processing plant, the cooperative delivered to most customers-independent restaurants, food-service institutions, caterers, churches, and independent "mom and pop" grocery stores. Figure 8 shows the percentage of delivery trips made directly to each type of customer using the leased 3/4-ton truck.

\section{Percentage of Deliveries}

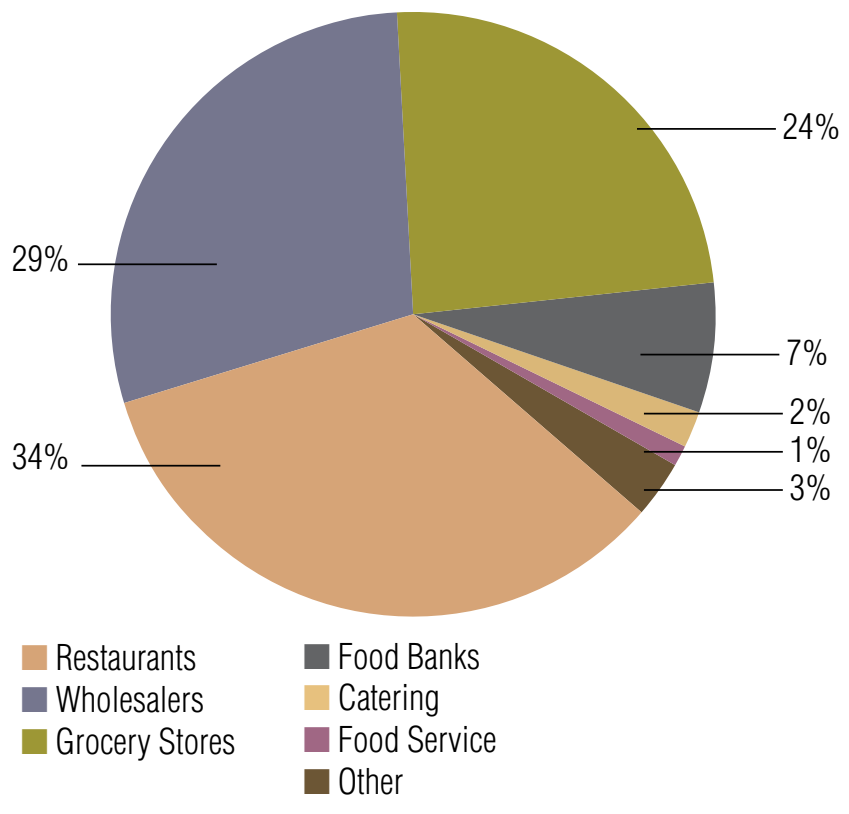

Figure 8. Share of direct deliveries by types of customer.

\section{Order Sizes and Types}

The typical order size was small, making it difficult to deliver on a cost-effective basis. Typical deliveries to restaurants and delicatessens were 30 pounds of non-fillet items and 60 pounds of fillets, and to local groceries 20 pounds of non-fillet items and 38 pounds of fillets. Even with careful planning, the small (two to four 15-pound boxes) deliveries made it difficult to operate the truck economically. It isn't surprising that as the cooperative's production capacity-and its ability to attract larger customers-increased, it preferred larger customers because of the lower cost of making multi-pallet deliveries.

\section{Deliveries to Restaurants}

Eighty percent of catfish deliveries to restaurants, delicatessens, and sandwich shops-the largest customer segment-weighed less than 100 pounds each (figure 9). A typical order consisted of one to five 15-pound cartons, with each restaurant receiving one or two deliveries a week. More than 100 restaurant deliveries a day would be required to fully utilize the cooperative's processing plant capacity of 5,000 pounds a shift. Even in rural Kentucky, where catfish is very popular, there aren't enough restaurants within delivery distance to absorb the cooperative's production capacity. The restaurant trade isn't unimportant, but the cooperative needs other customers that can absorb a greater volume of product.

\section{Number of Deliveries to Restaurants}

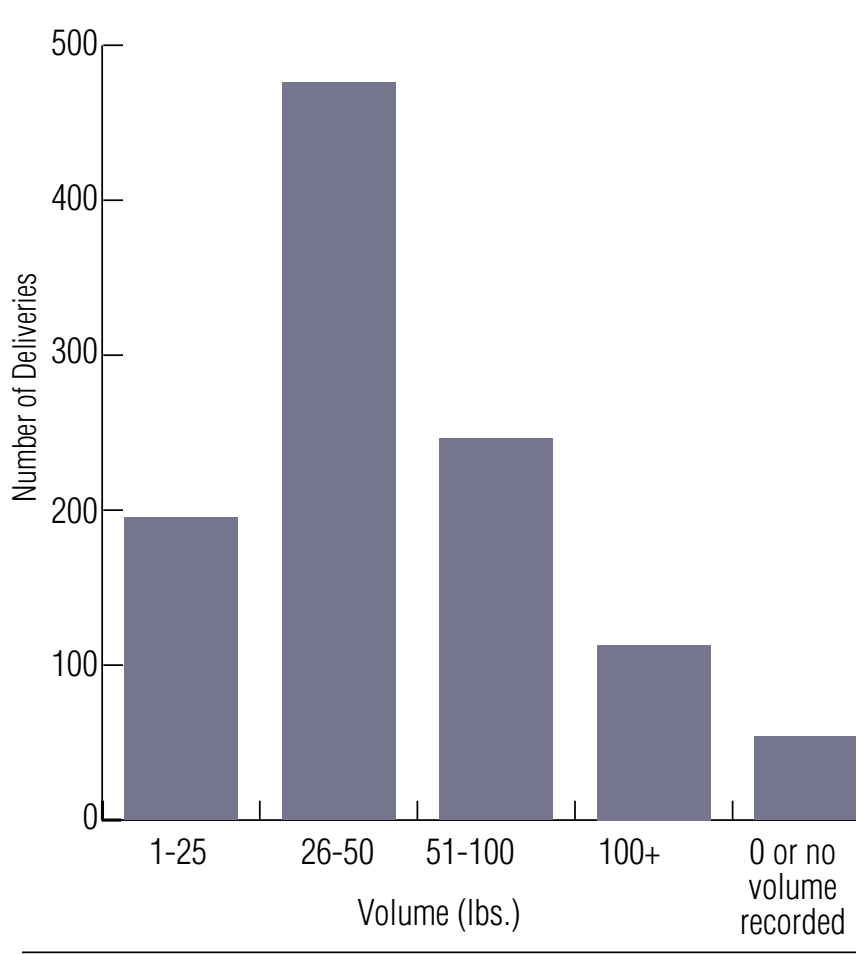

Figure 9. Restaurant deliveries by size of order. 


\section{Deliveries to Wholesalers and Distributors}

Deliveries to wholesalers and distributors were generally larger than those to restaurants; half of them were between 100 and 500 pounds (see figure 10). Because wholesalers and distributors purchase for redistribution, it is to be expected that their purchases are larger than retail businesses. Wholesalers had one other interesting characteristic: Of the three fillet sizes marketed by the cooperative ( 3 to 5 ounces, 5 to 7 ounces, and 7 to 9 ounces), wholesalers showed a marked preference for the largest size.

\section{Deliveries to Grocery Stores}

Most deliveries to the small grocery stores served by the cooperative were small (see figure 11). Typical orders consisted of a weekly delivery of a couple of 15-pound boxes of fish, with slightly larger deliveries when the store ran a special on catfish. Unlike restaurants, whose fish and seafood sales often exceed 20 percent of total sales, grocery stores carry a wide variety of other products, with seafood sales making up less than 5 percent of their business. Despite its popularity in the region, catfish represents only a fraction of the seafood category, so grocery stores provided only a modest outlet for the cooperative.

\section{Direct Deliveries to Food Banks}

Food banks, while infrequent customers, placed larger orders than most of the cooperative's customers. They also purchased some of the less popular catfish products at a discount, helping to move some of the cooperative's excess inventory. Despite food banks and pantries accounting for only 4 percent of the cooperative's sales (in pounds), they ordered more non-fillet items than other customers, and were the only customer to order more non-fillet items than fillets (again in pounds). Food banks and pantries purchased 29 percent of all non-fillet items, and accounted for 63 percent of all sales of frozen catfish strips and fingers. Food banks and pantries were also an important outlet for offgrade fillets, purchasing more than 5,000 pounds during the 12-month period.

\section{Number of Deliveries to Wholesalers}

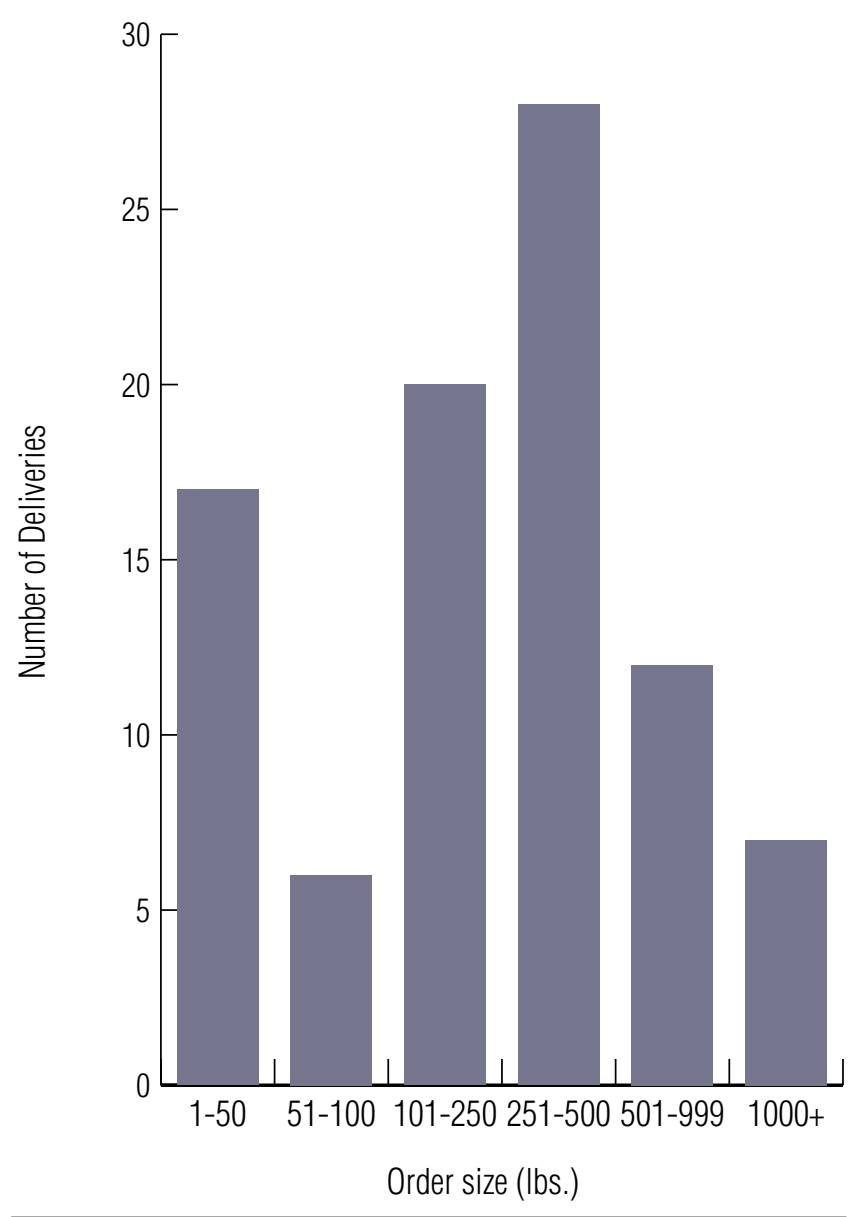

Figure 10. Deliveries to wholesalers by order size.

\section{Number of Deliveries to Grocery Stores}

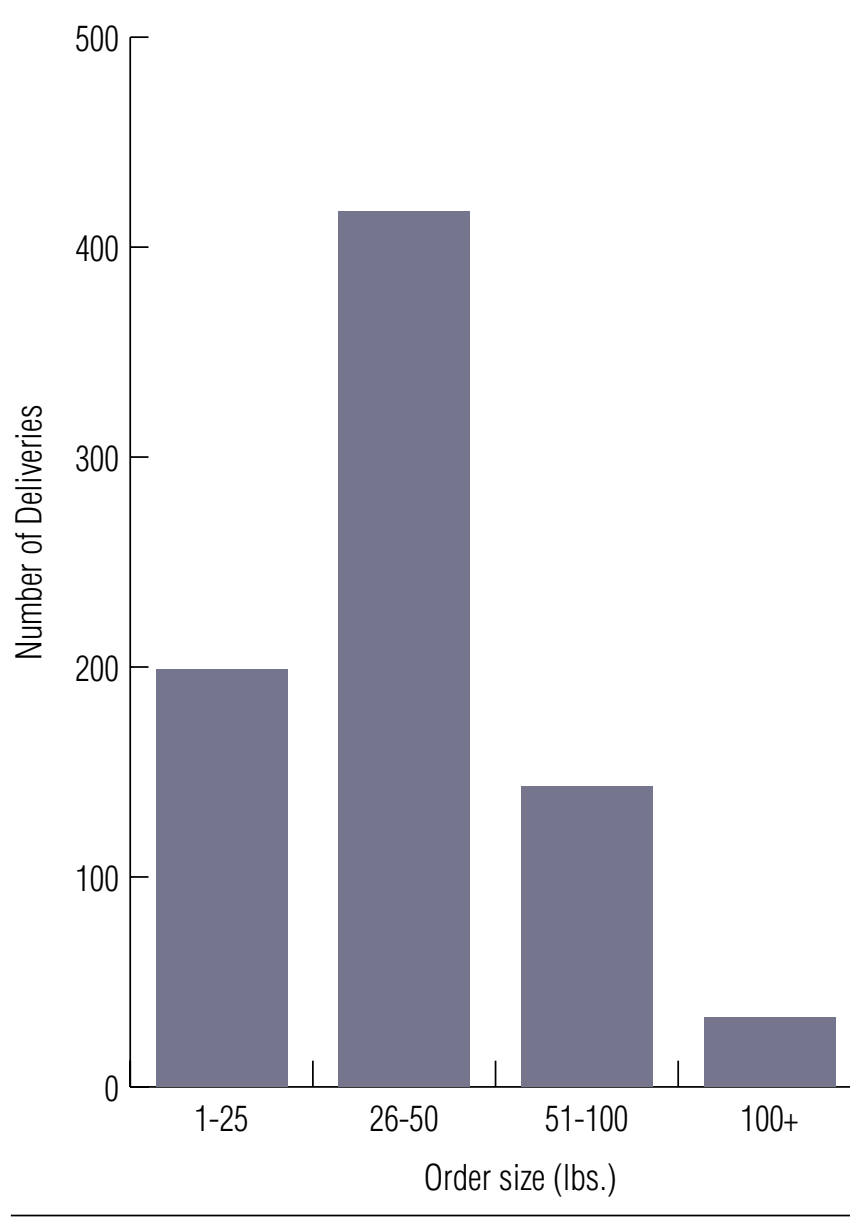

Figure 11. Direct deliveries to grocery stores by order size. 
The interest of food banks in a relatively high-value, perishable product like catfish exceeded expectations, since these customers primarily provide packaged and canned food with a long shelf life. However, the discounted catfish provided the opportunity to add inexpensive, high-quality protein to their customers' diets, protein that was familiar and acceptable. The protein portions of the customer "plate" are expensive, and food banks operate under heavy financial constraints.

Food bank orders were generally for products that either were not selling well (usually catfish nuggets), or had some slight cosmetic defect that made them difficult to sell commercially but didn't affect the wholesomeness of the food. These items were sold to food banks, generally at a substantial discount, for use in dinner programs or for donation to low-income families. Sales to food banks benefited both the cooperative and the food bank: The cooperative was able to free up valuable freezer space, recover some cost from items that other marketing channels would not accept, and build community goodwill. The food banks were able to purchase cosmetically imperfect catfish products to provide protein to low-income families at a reasonable cost.

Deliveries to food banks were generally larger than to other customers, with deliveries of 500 or 1,000 pounds quite common (see figure 12). The average delivery order to food banks and pantries varied from 663 pounds for frozen non-fillet items to as much as 1,000 pounds of chilled fillets. In comparison, restaurant and grocery customers typically ordered less than 60 pounds. The large orders by food banks reflected their large customer base and their considerable storage capacity. The large size of the orders simplified delivery logistics, making them more cost-effective than the small orders placed by most other customers. The lower delivery cost helped offset the lower price per pound the cooperative received for these orders.

\section{Marketing Successes}

The study revealed several interesting points about catfish sales by the cooperative, some that helped to market their products, and some that were disappointing. Among the successes was an interest by customers and the public in purchasing locally grown fish.

\section{Number of Deliveries to Food Banks}

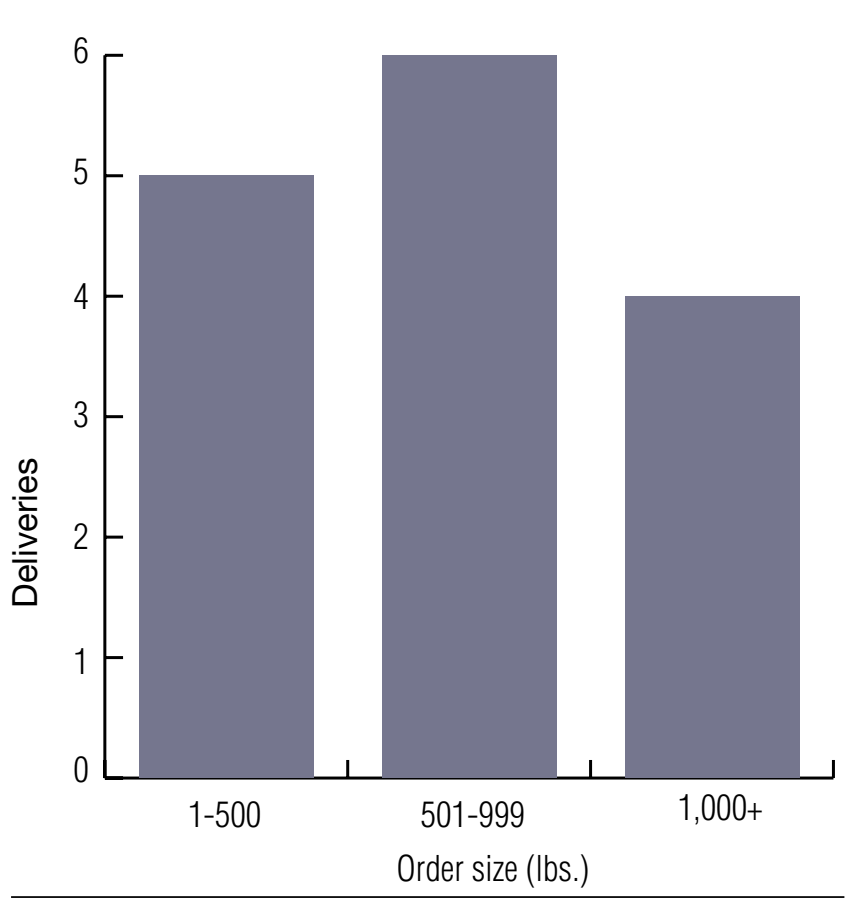

Figure 12. Deliveries to food banks by order size. 


\section{Consumer Interest in Local Farm Products}

One of the reasons for the success of the cooperative was its identity as a local producer. It was able to create interest in locally raised catfish products, which customers then exploited to differentiate their merchandise in a crowded and competitive marketplace. Both chain operations and independent businesses featured the cooperative's locally raised catfish as a way to attract customers. For example, several Kentucky affiliates of a regional fast-food chain made their business relationship with the cooperative an important part of their advertising, using in-store signs and promotional material to feature their sales of locally produced catfish, as illustrated by the photographs in figure 13. Smaller grocery stores and restaurants used placards and signs to announce the availability of locally produced catfish.

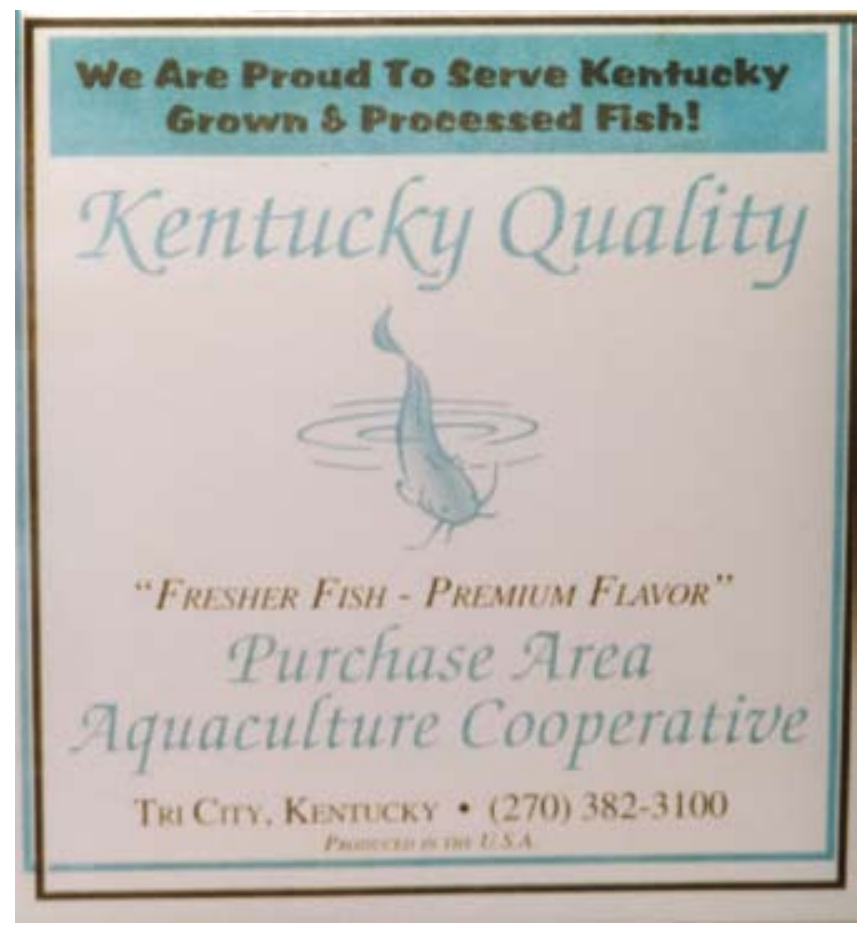

The Kentucky Department of Agriculture's Marketing Division actively promotes public interest in locally produced fish and other agricultural products through public announcements, press releases, web sites, ${ }^{9}$ and financial support. "Kentucky Pride" is a statewide program that promotes these Kentucky products. Sponsored events, such as the Kingfish Catfish Festival-jointly sponsored by a Louisville restaurant chain, a local financial institution, and the Kentucky Department of Agriculture-help the cooperative by raising public awareness of PAAC as a member of the local community.

\section{Sales to Food Banks and Caterers Helped Balance Inventories}

Although restaurants, wholesalers, and grocery stores are the foundation of the cooperative's business, PAAC also developed a handful of other customers who placed intermittent orders. These customers proved to be especially important because of their willingness to receive less desirable products, and to receive large quantities at one time.

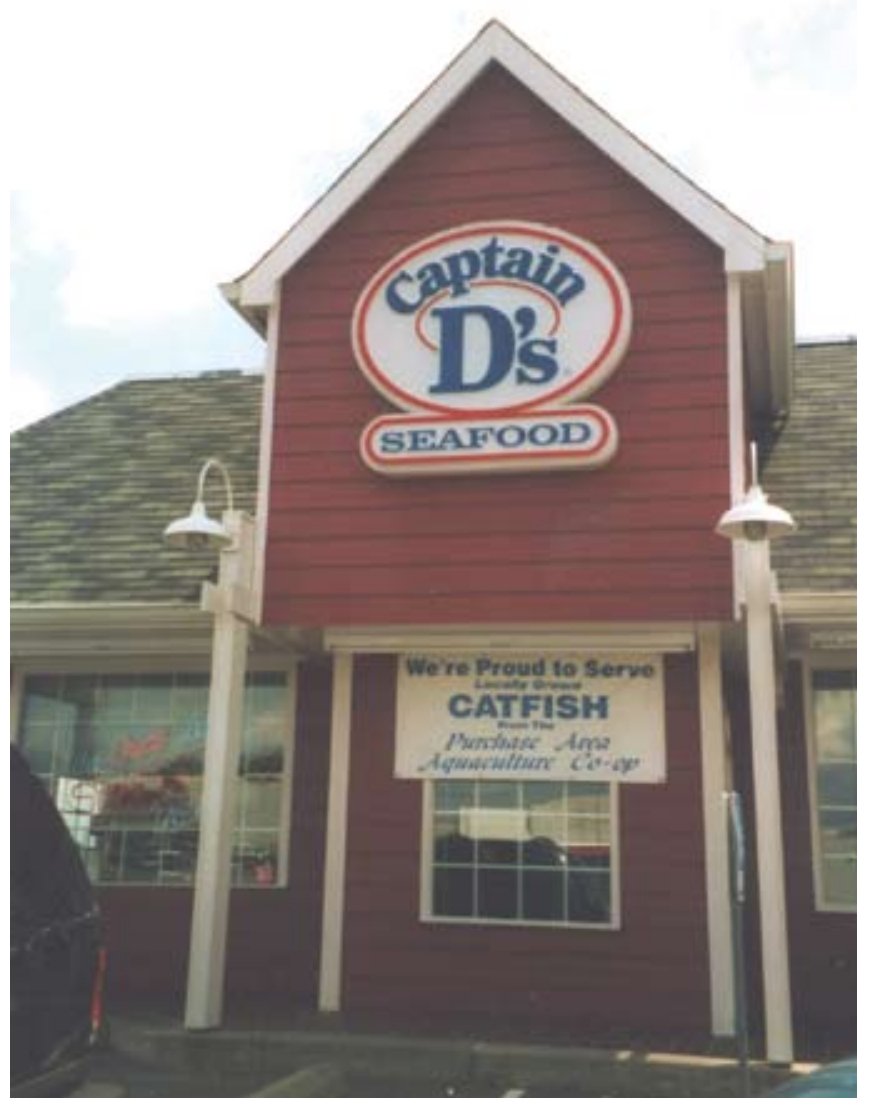

Figure 13. Banners and placards advertising local catfish at a restaurant in Murray, Kentucky.

\footnotetext{
${ }^{9}$ www.kyagr.com
} 
Foremost among these were local food banks (agencies that procure large amounts of food) and food pantries (local distribution sites that often receive food from food banks), which valued low-cost protein sources and were willing to accept cosmetically imperfect food. In addition, these institutions placed large orders, making delivery service economical.

PAAC's sales to catering firms and coordinators of special events also showed some attributes of food banks and pantries. Although caterers and coordinators of special events together accounted for just over 1 percent of the cooperative's delivery volume, their orders were much larger than those of restaurants and grocery stores. Deliveries to catering firms varied from 375 pounds of chilled fillets to 725 pounds of frozen fillets, and deliveries for special events, such as summer festivals and fairs, varied from 112 pounds of frozen fillets to 500 pounds of frozen non-fillet items.

These intermittent customers were so profitable, and so useful in purchasing slower moving products, that it would make strategic sense for catfish direct marketers to seek them out. Efforts to attract these customers would pay off in more economical deliveries and increased sales of slower moving items.

\section{Marketing Challenges}

Some of the cooperative's discoveries were disappointing. They had expected to sell more chilled fish to compete with inexpensive frozen fish, and to sell nuggets in about the same proportion as fillets. However, these expectations were not realized.

\section{Demand for Chilled Catfish Products Fell Short of Expectations}

PAAC members had initially hoped that their ability to deliver never-frozen, chilled catfish products from their local processing facility would provide a competitive advantage over other suppliers and perhaps gain them a premium price.

Until the cooperative began producing catfish in western Kentucky, most retailers and foodservice buyers in the region purchased frozen catfish manufactured by large-scale processors located in other Southern States, notably the delta region of Mississippi. The cooperative anticipated that many of the region's retail and foodservice buyers would embrace the opportunity to purchase fresh local catfish for the first time, and would value its higher quality and finer texture. However, the expected demand for chilled catfish never materialized. During the course of this study, nearly 85 percent of the cooperative's sales consisted of frozen products, and sales of frozen fillets outstripped those of chilled fillets by nearly six to one. Furthermore, even within the small segment of the marketplace that regularly purchased chilled catfish-primarily restaurants, delicatessens, and independent grocery stores_-sales of frozen catfish still exceeded those of chilled fish by a large margin, making up 61 percent of deliveries, compared with 39 percent for chilled products.

Anecdotal evidence, based on feedback from the cooperative's buyers, suggests there are three primary reasons why the chilled catfish products never found greater buyer acceptance. Because fish is so perishable, the cooperative's customers found it more convenient to buy and store frozen fish because their sales volumes were so low. In addition, some buyers had difficulty adjusting their recipes (such as batter mixes) to accommodate chilled catfish, encouraging them to buy the more familiar frozen items.

There is some evidence to suggest that regional influences might play a part in the preference for chilled or frozen fish. Gall and O'Dierno ${ }^{10}$ reported that 75 percent of U.S. East Coast restaurants preferred fresh chilled fish, while Riepe ${ }^{11}$ reported 80 percent of restaurants in the North Central region of the United States preferred frozen fish.

Retail and foodservice buyers in PAAC's trade area did not place a high value on the superior quality of chilled catfish. In fact, they generally preferred to work with frozen catfish. As a result, the cooperative had to struggle to distinguish its products, making it more difficult for the group to compete with other fish suppliers or to obtain a price premium for its unique product line.

\footnotetext{
${ }^{10}$ Gall, K. and L. O'Dierno, 1995, "Aquaculture marketing survey: consumers, retail stores, and food service in New York and New Jersey," New Jersey Department of Agriculture, New York Sea Grant, Northeast Regional Aquaculture Center.

${ }^{11}$ Riepe, J, "Marketing seafood to restaurants in the North Central Region" North Central Regional Aquaculture Center Fact Sheet Series 110. Purdue University.
} 


\section{Limited Demand for Non-Fillet Items Adds to Holding Costs}

While PAAC found it relatively easy to develop a market for its catfish fillets, it had difficulty developing markets for its other products. Fillets accounted for more than 91 percent of the cooperative's catfish deliveries. The cooperative had to store excessive inventories of non-fillet items because of their sluggish sales, adding to its cost of operation.

Much of PAAC's output of non-fillet items was sold to food distribution companies, who were reliable buyers of these products. Non-fillet products constituted 28 percent of their purchases, compared with less than 9 percent across all distribution channels.

\section{The Delivery System}

The cooperative made deliveries in two different ways: smaller deliveries were made directly to customers using a leased truck driven by a cooperative employee. Larger deliveries were made by contracted common carriers driving large refrigerated trucks or tractor-trailer rigs.

\section{Cost and Efficiency of Direct Delivery}

The majority of the cooperative's customers were located in the Jackson Purchase region of southwestern Kentucky, a rural area with a scattering of small towns. Customers were widely dispersed and most received small orders, making the cost of delivery an important part of the cost of doing business. If the cooperative was to operate on a sound financial basis, it was critical to examine the costs of delivering product.

Figure 14 shows the average cost of delivering 1 pound of fish with the leased truck. At the project's start, delivery cost about 80 cents per pound. As the number and size of orders increased, delivery costs fell to a low of 20 cents per pound, then rebounded slightly to 25 cents at the end of the study. This volatility can be explained by the dynamics of a rapidly growing firm just moving out of its start-up phase.

Another reason for the volatility was the procurement of a second, larger, truck. As business improved, larger orders were taken away from the small truck and given to the larger vehicle, limiting the smaller truck to small deliveries. As a result, the cost of delivery with the smaller truck never sank below a certain level, in this case about 20 to 25 cents a pound (figure 14). The average delivery cost was 32 cents a pound.

\section{Delivery Cost Price (per lb.)}

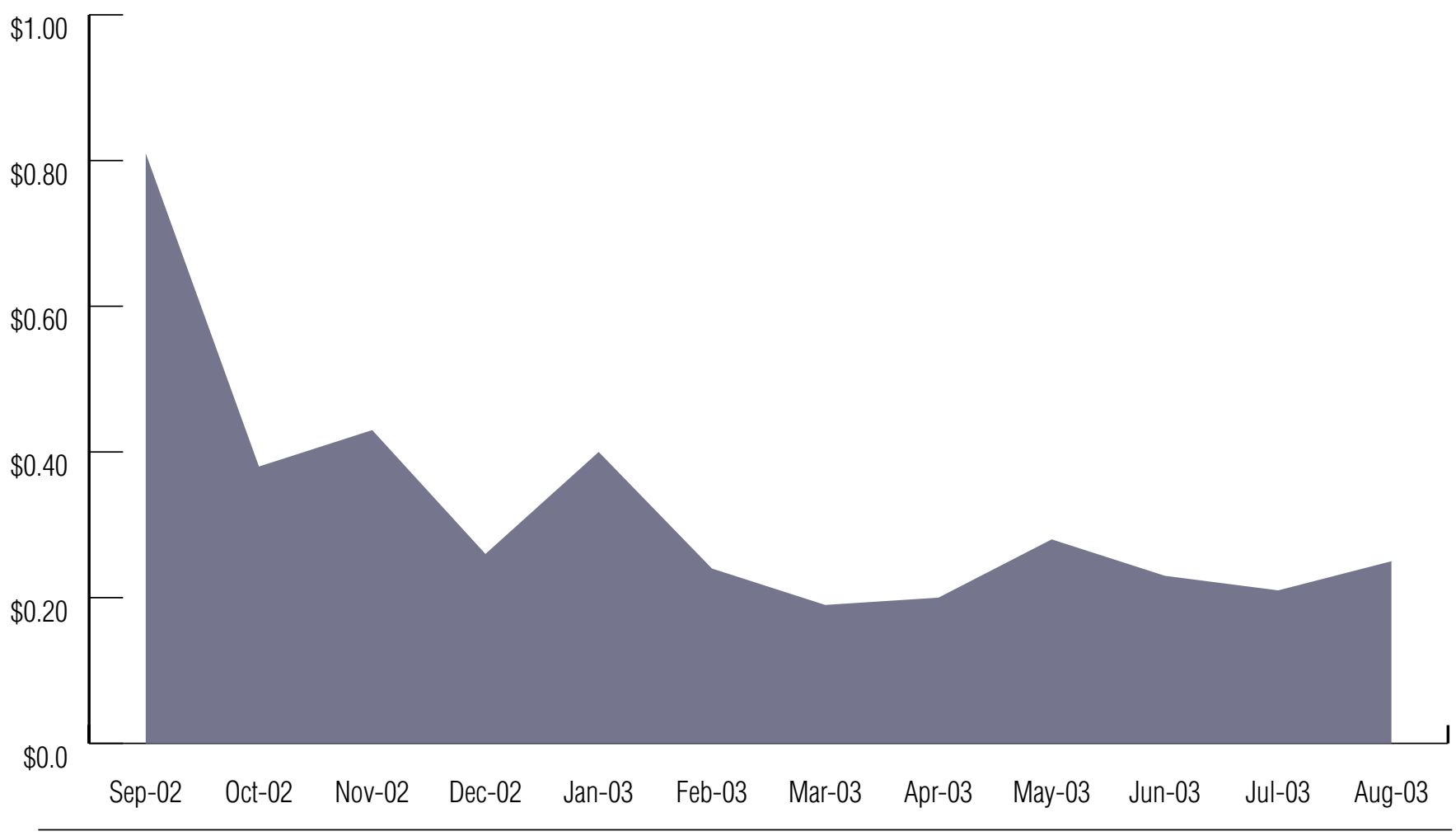

Figure 14. Average cost of delivery with the $3 / 4$ ton truck, by month. 


\section{Vehicle Operating Costs}

The monthly costs associated with direct deliveries can be divided into fixed and variable costs. Fixed costs are those associated with the ownership, lease, or rental of a delivery vehicle. They are independent of the operation of the vehicle-these charges accrue whether or not the truck moves. In general these fixed costs include:

- Leasing or rental fees

- Depreciation

- Insurance

- Registration/tags/permit fees

- Taxes

\begin{tabular}{|l|c|}
\hline \multicolumn{1}{|c|}{ Item } & Cost \\
\hline Chevrolet 2500 Diesel Pickup Truck & $\$ 30,000^{12}$ \\
Hercules Slip in Insulated Body & $\$ 5,000^{13}$ \\
Thermo King Refrigeration Unit & $\$ 6,200^{14}$ \\
Sub Total & $\$ 41,200$ \\
Sales tax (6\%) & $\$ 2,472$ \\
\hline & \\
\hline Total & $\$ 43,672$ \\
\hline
\end{tabular}

Table 1. Purchase price of truck, insulated freezer box and refrigeration unit (2002 dollars).

\section{Acquisition Cost}

In this study, the vehicle was leased. This is a common business practice because leasing provides a tax advantage; leasing costs are directly deductible as a business expense, but purchase costs must be depreciated over several years. For comparison purposes, table 1 gives the purchase price of a new 2003,3/4-ton, diesel-powered pickup truck equipped with an insulated slip-in freezer box and refrigeration unit, similar to the truck that was leased by the cooperative.

\section{Fixed Costs}

Table 2 shows the annual fixed costs of leasing the 3/4-ton refrigerated truck in 2003 dollars. The lease in this instance lasted for 2 years. It included an initial payment of $\$ 6,000$ and a final payment of $\$ 12,000$, due at the end of the lease. If the firm leasing the vehicle didn't wish to keep it at the end of the lease, the truck could be returned. However, the final payment would be due whether the vehicle was retained or returned. If returned, the final payment of $\$ 12,000$ would be reduced by the vehicle's remaining value as determined by the leasing firm. Table 2 illustrates that even with little use, leasing a delivery vehicle is very expensive-nearly $\$ 19,000$ per year.

${ }_{12}$ Edmunds, 2004, Vehicle purchase price and maintenance schedules. http://edmunds.com/.

${ }^{13}$ Thermo King of Maryland. Personal Communication.

14 lbid.

\begin{tabular}{|l|r|}
\hline \multicolumn{1}{|c|}{ Fixed Cost Items } & \multicolumn{1}{c|}{ Cost } \\
\hline Monthly Lease Payments (12 @ & $\$ 12,000$ \\
$\$ 1,000)$ & \\
Down Payment $(1 / 2 \$ 6,000)$ & $\$ 3,000$ \\
Final payment $(1 / 2 \$ 12000)$ & $\$ 6,000$ \\
Annual License \& Registration & $\$ 246$ \\
Insurance & $\$ 2682$ \\
Taxes (1/2 sales tax @ 6\%) & $\$ 861$ \\
\hline Total Annual Fixed Cost & $\$ 24,789$ \\
- Salvage Value (1/2 \$12,000) & $-\$ 6,000$ \\
Total Annual Fixed Cost & $\$ 18,789$ \\
\hline
\end{tabular}

Table 2. Annual fixed costs of 2-year lease on a 3/4-ton, refrigerated truck, September 2002-August 2003.

Variable costs. Variable costs are those costs that are incurred during the operation of the vehicle, such as:

- Fuel

- Oil

- Maintenance

- Repairs

- Tires

- Labor

Table 3 shows the variable operating costs of the leased truck. The vehicle was operated 202 days and was driven 75,978 miles during the time of the study. Based on this level of usage, the variable costs were $\$ 28,910$ a year, or 38 cents a mile. This exceeded the vehicle's fixed operating cost of $\$ 18,789$.

\begin{tabular}{|l|c|c|}
\hline \multicolumn{1}{|c|}{ Item } & Cost & Cost per mile \\
\hline Tires (4 tires every & $\$ 1,125$ & $\$ 0.01$ \\
$\quad$ 40K miles, @ & & \\
$\quad$ \$150 each) & $\$ 10,701$ & \\
Fuel & $\$ 2,661$ & $\$ 0.14$ \\
Maintenance & $\$ 1,495$ & $\$ 0.04$ \\
Repairs & $\$ 12,928$ & $\$ 0.02$ \\
Labor @ \$8/hour & & \\
$\quad$ (202 days) & & \\
\hline Total & $\$ 28,910$ & $\$ 0.38$ \\
\hline
\end{tabular}

Table 3. Annual variable operating cost for the 3/4-ton truck. 
To prepare this variable cost information, mileage was calculated using initial and final daily odometer readings, and an average fuel price of $\$ 1.69$ per gallon-the average price paid for fuel during the study. The average fuel cost of $\$ 1.69$ per gallon for on-road diesel fuel corresponds closely with the average weekly price reported by the U.S. Department of Energy (figure 15).

To compensate for the reported variability of fuel usage, a "typical" fuel economy value (12 miles per gallon) for the type of vehicle leased by the cooperative was substituted for calculation purposes. The unexpected fluctuations in the vehicle's recorded fuel usage over the course of the year may have been due to:

- Operator driving style

- Size of load

- Type of road condition (local heavy traffic or highway mileage)

- Outside temperature (hot weather increases cooling load)

- Amount of time idling during deliveries

- Use of vehicle for non-delivery purposes

- Spotty recording of fuel purchases

The calculation of variable operating costs (table 3 ) for the vehicle included estimated costs for tire replacement, refrigeration servicing, routine maintenance, and expected repairs. Routine maintenance costs were estimated using the factory-recommended list of services at the recommended intervals. The cost of services such as alignment, oil change, lubrication, filter changes, and tune-ups was included in the calculation. Expected repairs included such services as brake replacement and transmission overhaul. The operating cost calculations were made assuming 1 year's usage of 76,000 miles.
Figure 16 illustrates the share of operating cost contributed by each component. Table 4 provides a list of major operating costs, by mile and by year. Fixed costs (leasing, insurance, registration, and taxes) contributed the greatest portion of total vehicle cost. Fuel and labor were also significant factors. Probably because the vehicle was new, maintenance and repair costs were low, contributing less than 10 percent to the total cost.

\section{Share of Variable Operating Costs}

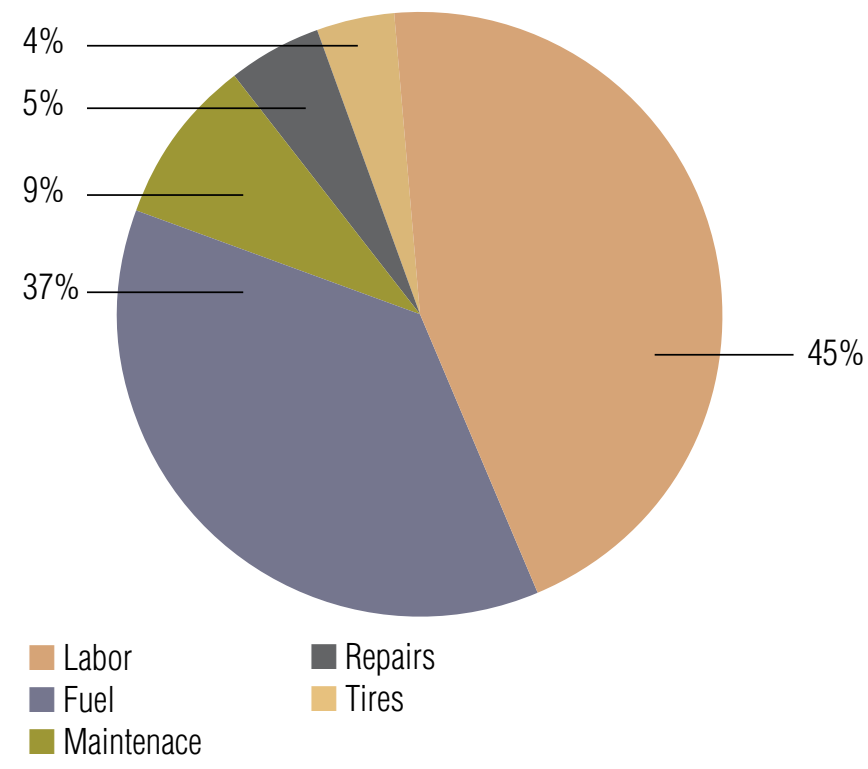

Figure 16. Analysis of variable operating costs.

\section{U.S. Retail Diesel Price (per gallon)}

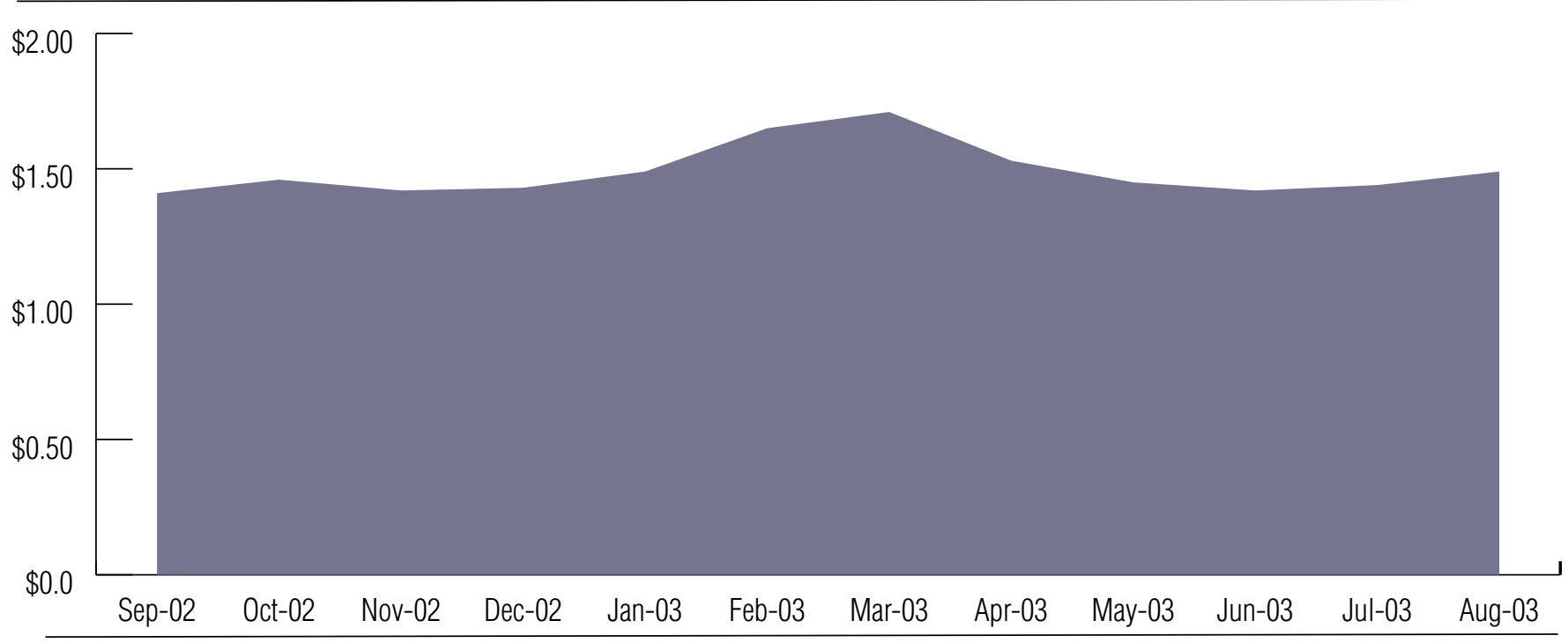

Figure 15. U.S. at-pump diesel fuel cost, September 2002-August 2003.

Source: U.S. Department of Energy, Energy Information Administration 


\begin{tabular}{|l|c|c|}
\multicolumn{1}{c}{ Item } & Gost per mile & \multicolumn{1}{c|}{ Annual Gost } \\
\hline Tires & $\$ 0.015$ & $\$ 1,125$ \\
Repairs & $\$ 0.020$ & $\$ 1,495$ \\
Maintenance & $\$ 0.035$ & $\$ 2,661$ \\
Fuel (@\$1.69/gal) & $\$ 0.140$ & $\$ 10,701$ \\
$\quad$ Labor & $\$ 0.170$ & $\$ 12,928$ \\
Fixed (lease, & $\$ 0.247$ & $\$ 18,789$ \\
$\quad$ insurance, taxes, & & \\
$\quad$ registration) & & \\
\hline Total & $\$ 0.627$ & $\$ 47,699$ \\
\hline
\end{tabular}

\section{Effect of Price Increases}

Because the cost of fuel and labor are such large components of the cost of delivery, changes in their costs have a major impact on truck operating expenses. The cost of fuel and labor together accounted for 82 percent of the vehicle's variable operating costs and 49 percent of the total operating expense (figures 16 and 17).

Because U.S. diesel fuel prices rose during the study, and have continued to rise since-from an average of $\$ 1.31$ a gallon in 2002 to $\$ 2.31$ a gallon in June $2005^{15}$-it is informative to investigate the effect of diesel fuel price increases

Table 4. Vehicle leasing and operating costs, by mile and by year.

As indicated in the previous section, the cost of fuel was a major component of the variable operating costs, second only to labor. Fuel constituted 37 percent of the variable operating cost and 22 percent of the total cost. Table 5 depicts the annual amount of fuel used. Based on an annual usage of 76,000 miles and an average fuel cost of $\$ 1.69$ a gallon during the study, the fuel component of operating costs was about 14 cents a mile, similar to the 17 cents a mile for the driver's labor.

\begin{tabular}{|c|l|}
\hline Annual Mileage & \multicolumn{1}{|c|}{$\mathbf{7 5 , 9 7 8}$ miles } \\
\hline Annual Fuel Cost & $\begin{array}{l}6,332 \text { gallons } \times \$ 1.69 \text { per gallon } \\
\text { (fuel at } 12 \mathrm{mpg} \text { ) } \\
=\$ 10,701\end{array}$ \\
\hline Fuel Cost per Mile & $\$ 0.14$ \\
\hline
\end{tabular}

Table 5. Annual mileage, fuel use, and fuel cost.

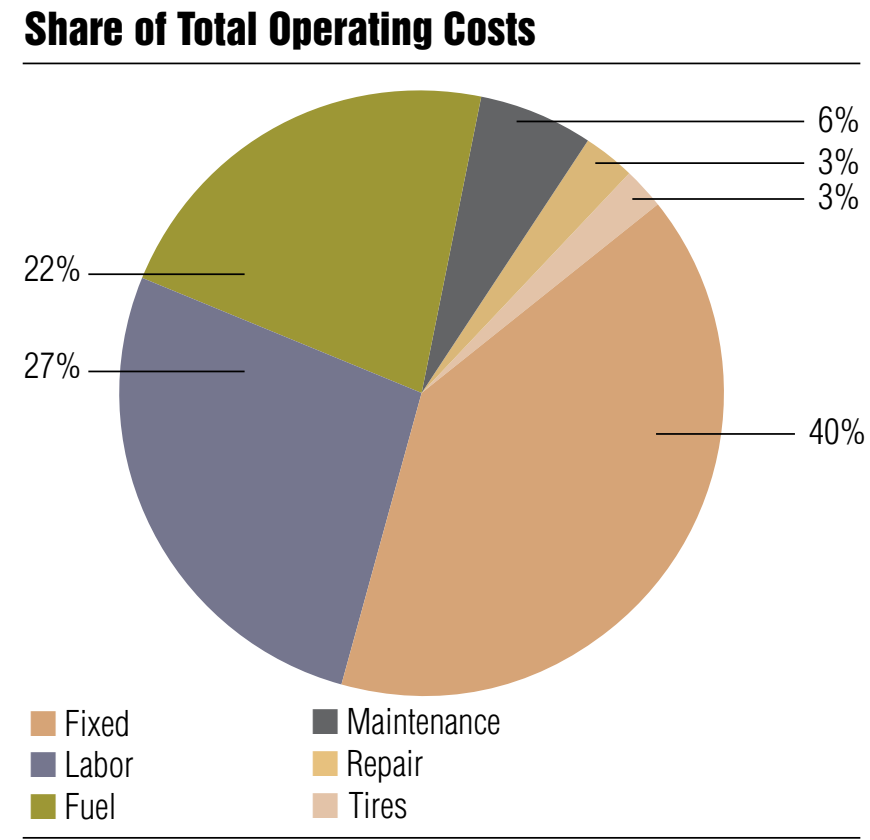

Figure 17. Share of cost components.

${ }^{15}$ Department of Energy, 2005, Weekly Retail Gasoline and Diesel Prices, Energy Information Administration, http://eia.doe.gov/. 
Figure 18 shows the average weekly U.S. no. 2 diesel price, as paid at the pump, from January 2002 through December 2004. Prices rose during the study and have continued to do so ever since.

\section{U.S. Retail Diesel Price (per gallon)}

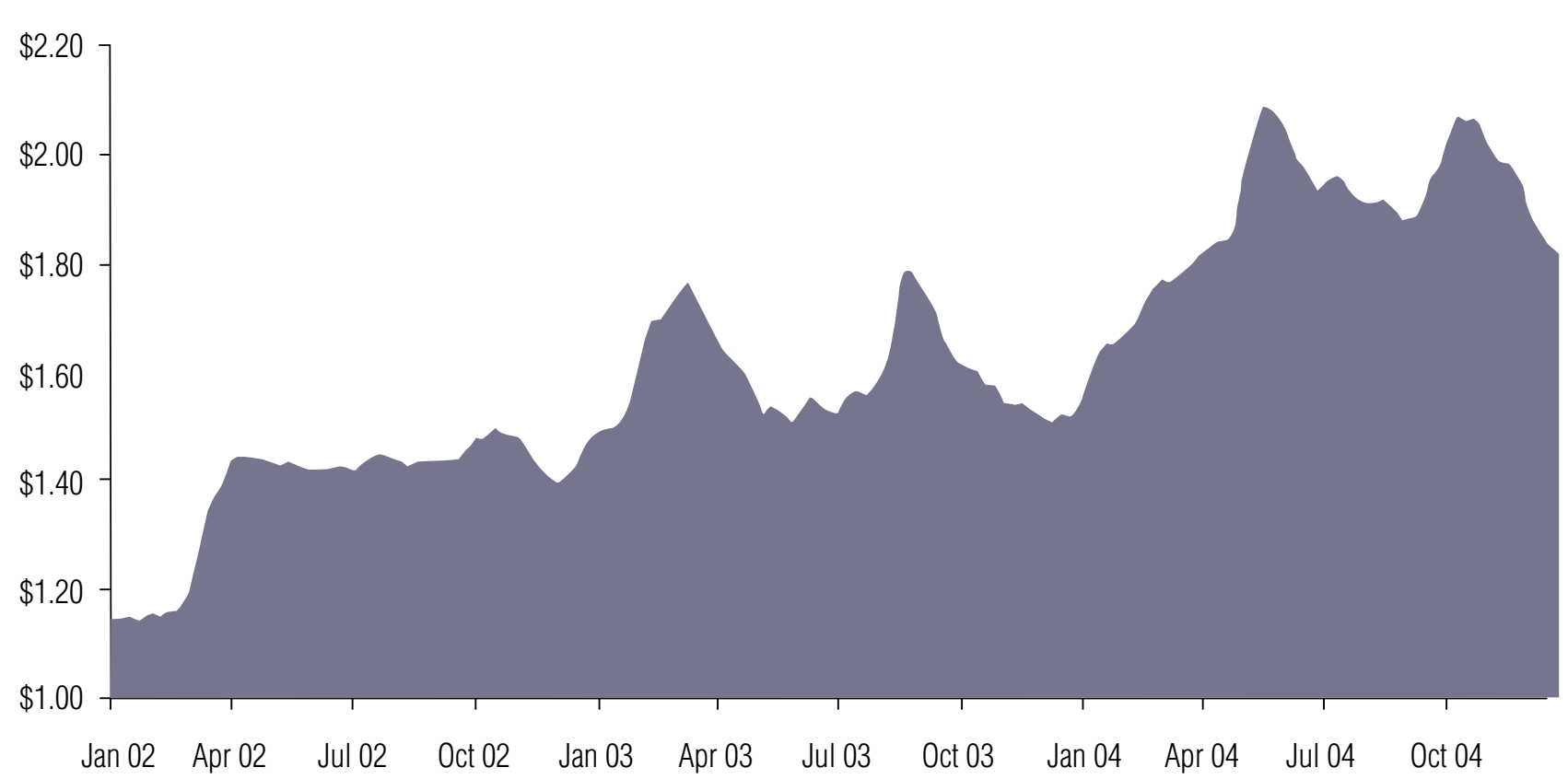

Figure 18. U.S. at-pump diesel fuel cost, January 2002-December 2004.

\section{Fuel Impact on Operating Cost (dollars/mile)}

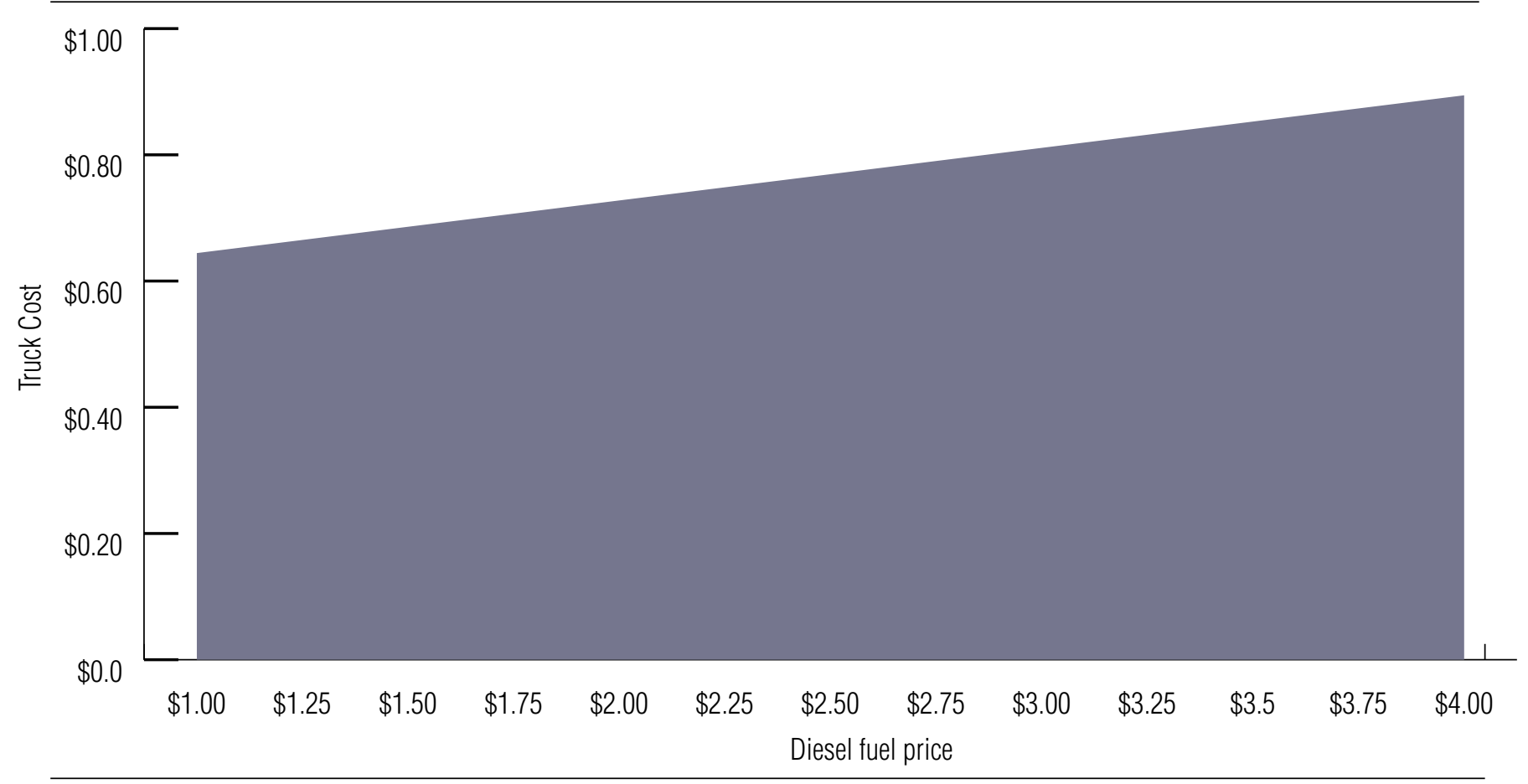

Figure 19. The effect of diesel fuel price increases on the operating cost of the cooperative's truck. 
As table 4 and figure 17 show, total vehicle operating cost is also dependent on the cost of labor. Surprisingly, PAAC reported a total driver labor cost of only $\$ 8$ an hour, although the median salary for general delivery drivers in 2002 was nearly $\$ 10$ an hour, and was as high as $\$ 14.98$ for drivers in the specialty food delivery segment. ${ }^{16}$ Including the cost of social security taxes, unemployment insurance, and benefits would increase the total cost of general delivery drivers to an estimated \$13 an hour and of food drivers to \$21 an hour. Because of this $\$ 5$ to $\$ 13$ an hour difference in total salary costs, AMS researchers investigated the impact of labor cost increases as well as changes in fuel prices.

Figure 20 examines the effect that changes in the total hourly rate package of the driver for the cooperative would have on total vehicle operating cost. With the cost of a driver's salary ranging from $\$ 12$ and $\$ 20$ an hour-more typical than the $\$ 8$ an hour paid by the cooperative - the delivery truck's operating cost would fall between 71 and 88 cents a mile. This is equivalent to a 2-cents-a-mile increase in operating cost for every dollar increase in a driver's wages.

${ }^{16}$ Bureau of Labor Statistics, 2005, "Truck Drivers and Driver/Sales Workers," Occupational Outlook Handbook, 2004-05 Edition, http://www.bls.gov/oco/ ocos246.htm\#earnings.

\section{Labor Impact on Operating Cost (dollars/mile)}

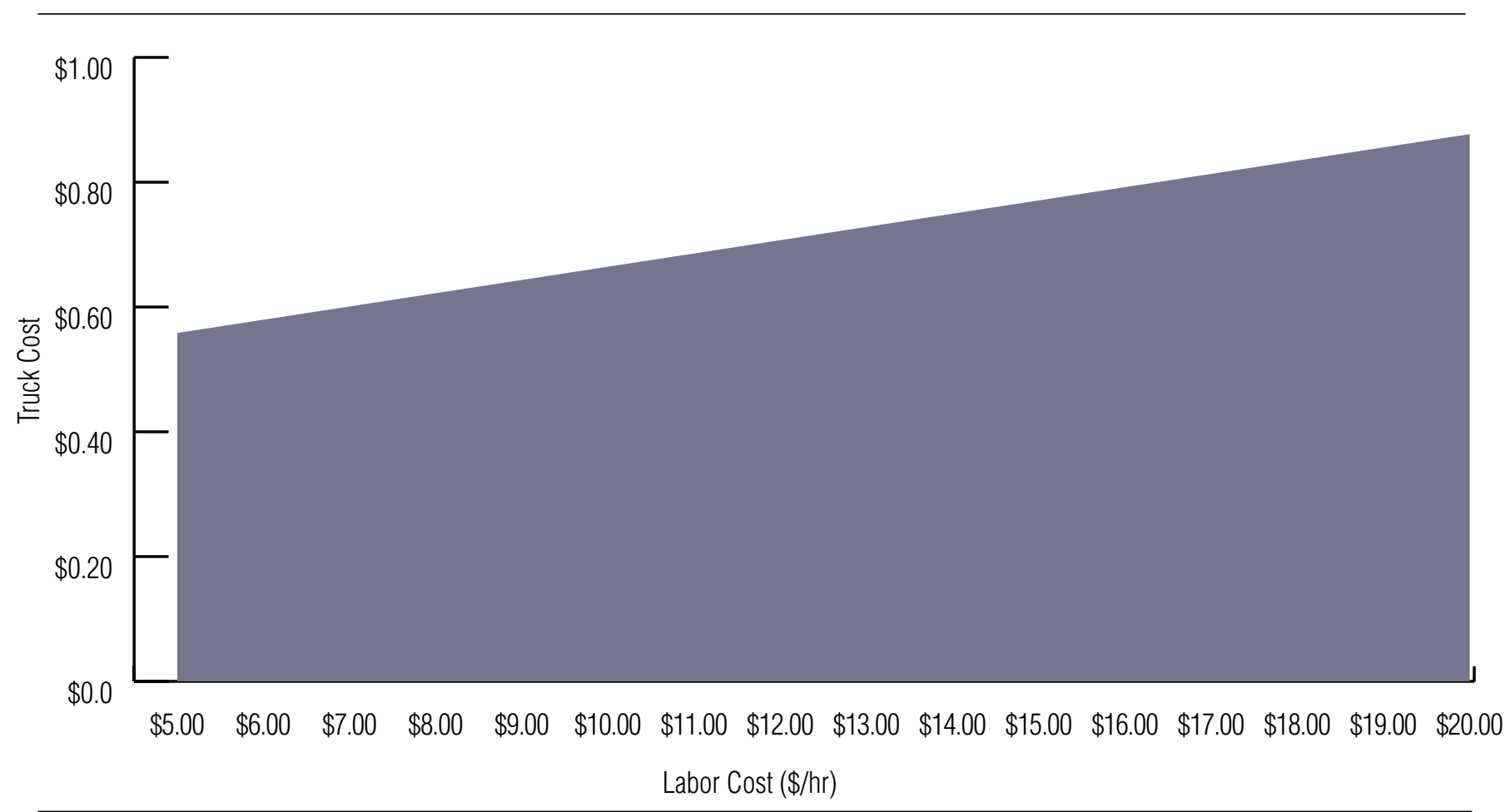

Figure 20. The effect of driver salaries on vehicle operating cost.

\section{Contract Hauling}

The cooperative used contract haulers to deliver large orders to a distribution warehouse. The contract haulers provided a truck, driver, and a refrigerated trailer. They charged a fee based on mileage, plus additional fees for time waiting to load and unload. In most cases, 20-pound packages of frozen fish were loaded by hand, stacking them on pallets in a tractor-trailer. Then they were hauled to Indianapolis and unloaded with a forklift for inspection, reloaded, and hauled to the customer's distribution warehouse in Louisville. Occasionally, the load was delivered directly to the customer without inspection, or delivered to or from an off-site storage facility. In a few cases, the cooperative used its own medium-duty refrigerated truck for off-site storage delivery.

Inspection is not required by law for domestic shipments of fish, but the cooperative's retail customer required U.S. Department of Commerce inspection, and the nearest inspection station was at the Interstate Warehouse in Indianapolis.

Deliveries by contract haulers involved more cost factors than those with the leased truck. These included additional costs for palletizing the merchandise, unloading and reloading the merchandise at the inspection station, inspection fees, and mileage charges. Moreover, the use of contract haulers and the complexity of delivering product at a distribution center usually included more prolonged waiting periods per delivery.

The contract haulers used either 48-foot or 53-foot refriger- 
ated tractor-trailers. A 48-foot trailer can carry 20 singlestacked pallets. A 53-foot trailer carries 22 single-stacked pallets. Mileage charges were the same whether the truck was fully or partially loaded. Table 6 shows typical costs for delivery of partial and full loads on a 48-foot refrigerated trailer from the processing plant to Louisville via Indianapolis.

Delivery costs were not directly dependent on the pounds of fish shipped. The mileage cost depended on the number of miles traveled and was independent of the number of pallets shipped. Inspection also cost less per pound for larger shipments. Other costs, such as purchasing pallets ( $\$ 5$ each) or unloading and loading pallets for inspection (\$20 per pallet) depended on the number of pallets. Because of the fixed mileage charge, shipping a pound of fish in a full trailer is much less expensive than in a partially filled one.

\section{Conclusions}

The findings of the study can be divided into three categories: marketing, material handling, and delivery.

\section{Marketing}

- Local identity is a strong marketing tool for small food producers. PAAC's sales were helped by the recognition, loyalty, and demand of consumers. Groceries and restaurants recognized this loyalty and advertised the fish as local.

- The market for chilled catfish was limited because of local custom and the convenience of frozen fish. Contrary to initial expectations, the cooperative was unable to develop a market for its unique line of fresh catfish.

- Products other than fillets did not sell well, probably because of unfamiliarity or inconvenience (in the case of fiddlers).
- Food banks were convenient outlets for excess inventory and fish with cosmetic flaws. Although they purchased at a substantial discount, they bought large amounts of fish as a source of inexpensive protein for their clients.

\section{Material Handling and Storage}

- Inefficient procedures for loading trucks added significantly to costs, especially at higher levels of production.

- Lack of storage space necessitated the use of off-site and temporary storage. This added to both the trucking and handling costs.

\section{Delivery}

- Direct delivery with a $3 / 4$-ton refrigerated truck was expensive. It cost the cooperative nearly $\$ 48,000$ per year (63 cents a mile, or 30 cents per pound of delivered fish).

- Although delivery cost per pound to the large chain grocery was lower than to local customers, the savings was somewhat offset by the chain's requirements for packaging, labeling, and inspection.

\section{Improving the Delivery Operation}

Here are a few recommendations that would help the PAAC — and small agricultural marketers like it-lower their delivery costs.

- Improve the truck loading process with truck-height loading docks, pallet lifters, a fork lift, and banding and wrapping equipment. This would reduce labor costs and speed up operations.

- Increase the on-site freezer storage. Using off-site storage costs the cooperative in speed and flexibility of delivery as well as in rental and delivery expense.

- Improve training and add incentive pay for drivers delivering directly to customers. Because of their customer contact, drivers could boost sales substantially. Without driver training or incentives, the cooperative misses an opportunity to suggest products or discover problems or untapped sales potential.

\begin{tabular}{|c|r|c|c|c|c|c|c|c|c|}
\hline Pallets & $\begin{array}{c}\text { Pallet } \\
\text { Cost }\end{array}$ & Weight & Load & Inspect & Unload & Miles & Trucking & Total & Cost/lb \\
\hline $1^{*}$ & $\$ 5$ & 1,200 & $\$ 12$ & $\$ 204$ & $\$ 20$ & 435 & $\$ 570$ & $\$ 811$ & $\$ 0.676$ \\
\hline 7 & $\$ 35$ & 8,400 & $\$ 24$ & $\$ 306$ & $\$ 140$ & 435 & $\$ 570$ & $\$ 1,075$ & $\$ 0.128$ \\
\hline 14 & $\$ 70$ & 16,800 & $\$ 48$ & $\$ 612$ & $\$ 280$ & 435 & $\$ 570$ & $\$ 1,580$ & $\$ 0.094$ \\
\hline 20 & $\$ 100$ & 24,000 & $\$ 96$ & $\$ 612$ & $\$ 400$ & 435 & $\$ 570$ & $\$ 1,778$ & $\$ 0.074$ \\
\hline
\end{tabular}

Table 6. Cost of contract delivery.

* Single pallet loads were not shipped via tractor-trailer. This value is shown here for comparative purposes only. 


\section{Appendix}

Price list for walk-in customers at the cooperative's processing facility

\begin{tabular}{|c|c|c|}
\hline Item & Price per Pound & Price per 15 /b Box \\
\hline Nuggets & $\$ 1.50$ & $\$ 19.00$ \\
\hline Fiddlers/Whole & $\$ 2.80$ & $\$ 40.00$ \\
\hline Fillet Strips & $\$ 3.85$ & $\$ 54.00$ \\
\hline Fillets & $\$ 2.98$ & $\$ 44.70$ \\
\hline Steaks & $\$ 3.35$ & $\$ 48.00$ \\
\hline Deep Skinned Fillets & $\$ 4.00$ & $\$ 57.00$ \\
\hline
\end{tabular}




\section{Bibliography}

Bloomburg. 2005. "Wal-Mart grocery sales rise 2.5\%."

Business Day. 29 May.

http://www.biz-day.com/read/commodities/.

Bureau of Labor Statistics. 2005. "Truck Drivers and

Driver/Sales Workers." Occupational Outlook

Handbook, 2004-05 Edition.

http://www.bls.gov/oco/ocos246.htm\#earnings.

Department of Energy. 2005. Weekly Retail Gasoline and Diesel Prices, Energy Information Administration.

http://eia.doe.gov/.

Economic Research Service, USDA. 2002. "Food market structures," Briefing Room

http://www.ers.usda.gov/Briefing/FoodMarketStructures/.

Edmonds. 2004. Vehicle purchase price and maintenance schedules. http://edmunds.com/.

Elitzak, H. 2001. USDA, Economic Research Service,

"Food Marketing at a glance," Food Review. http://www.ers.usda.gov/publications/FoodReview/ septdec01/FRv24i3g.pdf.

Feedstuffs. "Wal-Mart dominates all grocery industry," July 11,2005

Food Routes. 2005. Buy Fresh, Buy Local campaign. http://www.foodroutes.org/.

Gall, K. and L. O’Dierno. 1995. “Aquaculture marketing survey: consumers, retail stores, and food service in New York and New Jersey." New Jersey Department of Agriculture, Northeast Regional Aquaculture Center.
Gordon, Rosemary. "Support your local grower," American Vegetable Grower, September 2004.

Minnesota Department of Transportation. 2003. The Per Mile Costs of Operating Cars and Trucks. Research Report.

Oligopoly Watch. "Slotting fees and oligopolies." May 8, 2003. http://www.oligopolywatch.com/2003/05/08.html.

Pyle, R. "Statement before the Federal Trade Commission slotting fees hearing by Robert N. Pyle, President, Independent Bakers Association." Federal Trade Commission, November 8, 1995.

http://www.ftc.gov/opp/global/slott.htm.

Riepe, J. R. 1999. "Marketing seafood to restaurants in the North Central Region," North Central Regional Aquaculture Center Fact Sheet Series \#110. Purdue University, West Lafayette, IN.

Runzheimer International. 2003. Runzheimer Analyzes 2004 Car Van and Light Truck Costs. www.runzheimer. com/corpc/news/scripts/121003.asp.

Tropp, D. and S. Olowolayemo. 2000. How local farmers and foodservice buyers are forming alliances. USDA, Agricultural Marketing Service. Available on the Internet at http://www.ams.usda.gov/tmd/MSB/PDFpubList/localfarmsandschool.pdf.

Tuscarora Organic Growers. 2005. http://www.tog.coop/.

Wellborn, T. L. 1988. Channel Catfish: Life History and Biology. Southern Regional Aquaculture Center Publication No 180. Texas Agricultural Extension Service. http://aqua. ucdavis.edu/dbweb/outreach/aqua/180FS.PDF. 
28 Delivering the Goods: Lessons Learned from Direct Delivery of Kentucky Catfish 